\title{
A Review of Recent Advances in Hybrid Natural Fiber Reinforced Polymer Composites
}

\author{
Jorge Neto, Henrique Queiroz, Ricardo Aguiar, Rosemere Lima, Daniel Cavalcanti and \\ Mariana Doina Banea
}

Federal Centre of Technological Education in Rio de Janeiro (CEFET/RJ), Rio de Janeiro, Brazil

${ }^{*}$ Corresponding Author: Mariana Doina Banea. Email: mdbanea@gmail.com

Received: 10 May 2021 Accepted: 23 June 2021

\begin{abstract}
Natural fiber reinforced polymer composites (NFRCs) have demonstrated great potential for many different applications in various industries due to their advantages compared to synthetic fiber-reinforced composites, such as low environmental impact and low cost. However, one of the drawbacks is that the NFRCs present relatively low mechanical properties and the absorption of humidity due to the hydrophilic characteristic of the natural fibre. One method to increase their performance is hybridization. Therefore, understanding the properties and potential of using multiple reinforcement's materials to develop hybrid composites is of great interest. This paper provides an overview of the recent advances in hybrid natural fiber reinforced polymer composites. First, the main factors that affect the performance of hybrid fiber-reinforced composites were briefly discussed. The effect of hybridization on the mechanical and thermal properties of hybrid composites reinforced with several types of natural fibers (i.e., sisal, jute, curauá, ramie, banana, etc.) or natural fibers combined with synthetic fibers is presented. Finally, the water absorption behaviour of hybrid fiber-reinforced composites is also discussed. It was concluded that the main challenges that need to be addressed in order to increase the use of natural-natural or natural-synthetic hybrid composites in industry are the poor adhesion between natural fibers and matrix, thermal stability and moisture absorption of natural fibers. Some of these challenges were addressed by recent development in fibers treatment and modification, and product innovation (hybridization).
\end{abstract}

\section{KEYWORDS}

Natural fiber composites (NFC); hybrid composites; mechanical properties; thermal properties; water absorption

\section{Introduction}

Several industrial sectors (e.g., the automotive and aeronautics), are continuously seeking development of lighter materials with increased resistance with the goal of improving system reliability and efficiency. Therefore, composite materials present an excellent solution to this demand, especially the fiber reinforced polymeric composites, due to their high strength and stiffness, as well as presenting low density [1]. Nowadays, the industry is looking for new characteristics of composite materials, such as renewability, low environmental impact and cost. Consequently, there is an increasing augment in research and innovation in the natural fiber reinforced composite (NFRC) materials, mainly due to the advantages of these materials compared to synthetic fibre-reinforced composites, such as low 
environmental impact and low cost. However, one of the shortcomings is that the NFRCs present relatively low mechanical properties. One method to increase the mechanical performance of NFRCs to extend their applications is the hybridisation [2,3]. Hybrid composites use different reinforcement fibers, which can be arranged in a random, layer-by-layer or in-yarn manner [2]. The possible combinations of fibers in hybrid composites include synthetic-synthetic, natural-synthetic and natural-natural fiber types.

It is worth mentioning that the main natural fibers studied and applied in industry (i.e., jute, sisal, oil palm, kenaf, and flax) are well established on the global market with a well-defined production line. However, new promising types of natural fibers are being discovered and used on a smaller scale or are still being used only for research. It is the case of the buriti and curauá fibres, for example, that still need some improvements in their production line to be more commercially affordable and widespread used [4-6]. Another relevant factor in using natural fibers as reinforcement materials in composites is their eco-friendliness associated with lower energy consumption in their manufacturing process [7]. Nevertheless, its recyclable properties depend also on the type of matrices used in the composite production and the management of residuals produced by superficial treatments used to improve the adhesion between fiber/matrix [8].

Natural fiber reinforced polymer composites have demonstrated outstanding potential for many different applications in various industries such as automotive, domestic furniture, food packaging, and agricultural industry [7,9-11]. The growing importance of natural fiber reinforced composites is reflected by the increasing number of publications (e.g., reviews, patents, book chapters and books) during the recent years [12-17]. Although there are several reviews concerning the use of natural fibers in the production of natural hybrid composites, this paper provides an overview of the recent advances in both interlaminar and intralaminar hybrid natural fiber composites with natural-synthetic and natural-natural fiber combination in thermoset polymeric matrices. First, the main factors that affect the performance of hybrid fiber-reinforced composites were discussed. The effect of hybridization on the mechanical and thermal properties of hybrid composites reinforced with several types of natural fibers (i.e., sisal, jute, curauá, ramie, banana, etc.) or natural fibers combined with synthetic fibers is presented. Finally, the water absorption behaviour of hybrid fiber-reinforced composites is also discussed.

\section{Main Factors that Affect the Performance of Hybrid Fiber-Reinforced Composites}

The main factors that affect the performance of hybrid fiber-reinforced composites (types of fiber and resin, and the effect of fiber surface treatment), are briefly discussed in this section.

\subsection{Type of Fiber}

The natural fibers are promising renewable alternatives to the traditional human-made fibers (i.e., glass and carbon fibers) in composite materials. Their consumption is increasing in different industrial sectors, such as aeronautical, automotive, civil, and naval, with an average annual growth of $7.5 \%$ and an expected global market demand around of 35 million tons by 2022 [16].

The natural fibers can be divided into three main groups regarding their origin: mineral, animal and cellulose/lignocellulose (see Fig. 1). Mineral-based fibers were widely used in composite materials. However, their use presented many human health issues (carcinogenic parts that can be inhaled or ingested), nowadays being forbidden in many countries worldwide. The animal fibers present lower mechanical properties compared to the cellulose fibers, except for the silk fiber that presents high tensile strength. However, the silk fibers are quite expensive and are more used in the textile industries [1]. The animal fibers (i.e., protein fibers such as silk and wool) and the mineral fibers are not covered in this review. 


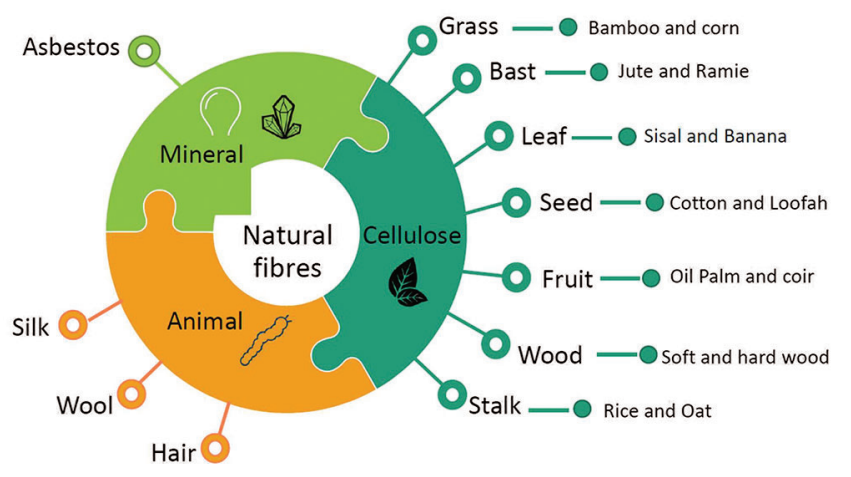

Figure 1: Schematic of natural fibers classification

The cellulose/lignocellulose fibers are the most used natural fibers due to their relatively low price and higher mechanical properties compared to other natural fibers. They can also be subdivided into different categories corresponding to the plant part that originated them.

The cellulose/lignocellulose fibers are primarily composed of cellulose ( $\alpha$-cellulose), hemicellulose and lignin [18]. They also present small quantities of waxes in their outer part. The chemical composition and cell structure of cellulose fibers are somewhat complicated $[19,20]$. Each fiber is basically a composite in which rigid cellulose microfibrils are embedded in a lignin and hemicellulose matrix. Moreover, the microfibrils are helically wound along the fiber axis to form hollow cells. For instance, the curauá, jute, and sisal fiber morphology are different with distinct lumen diameters $(4,6$ and $8 \mu \mathrm{m}$, respectively) and cell wall thickness [10,21]. Besides, they also present different percentages of lignin, cellulose and hemicellulose in their configuration. It is worth mentioning that the amount of cellulose and lignin in the natural fibers depends on the environmental conditions during the plant cultivation, soil properties, irrigation, and extraction techniques (i.e., automatic harvesting or manual extractions) [22]. These characteristics changes the natural fiber's morphology, and consequently, their mechanical and thermal properties [23-27]. The main mechanical properties of the most used natural fibers in hybrid composite materials and their cellulose content are summarised in Tab. 1. The tensile strengths and Young's moduli of these natural fibers cover an extensive range of values with typical tensile strength in the range of 100 to $1000 \mathrm{MPa}$ (except for the curauà fibers), which are generally lower than the properties of synthetic fibers (e.g., the tensile strength of E-glass fiber is about 2000-3500 MPa).

Generally, the fibers with higher cellulose contents present higher tensile strength and Young's modulus values (i.e., curauá, sisal and ramie). However, the high variability in fiber quality, which leads to high scattering in the material property values, is still a limitation, showing that many factors can influence their behaviour as the already cited environmental and processing conditions. Therefore, more studies about these parameters are necessary, especially in consideration to the fiber's conservation techniques. Another relevant issue is the lack of detailed information about single-fiber experimental testing procedures, making it difficult to compare the results obtained from different studies. Usually, these results are based on the sample's total cross-section, and its non-corrected measurement can significantly affect the tensile strength results, explaining the different values found in the literature [1].

Synthetic fibers like glass, carbon and aramid are being used in hybrid polymer-based composites mainly because of their high stiffness and strength properties [28]. However, the main drawbacks of using these fibers are their biodegradability, initial processing costs, recyclability, energy consumption, machine abrasion, health hazards, etc. 
Table 1: Mechanical properties of several cellulose fibers [10,18,22,29-32]

\begin{tabular}{|c|c|c|c|c|c|c|c|}
\hline Fiber & $\begin{array}{l}\text { Density } \\
\left(\mathrm{g} / \mathrm{cm}^{3}\right)\end{array}$ & Length (mm) & Diameter $(\mu \mathrm{m})$ & Elongation (\%) & $\begin{array}{l}\text { Tensile strength } \\
(\mathrm{MPa})\end{array}$ & $\begin{array}{l}\text { Young's modulus } \\
(\mathrm{GPa})\end{array}$ & $\begin{array}{l}\text { Cellulose content } \\
\text { (\% in weight) }\end{array}$ \\
\hline Jute & 1.23 & $0.8-6$ & $5-25$ & $1.5-3.1$ & $187-773$ & $20-55$ & $45-63$ \\
\hline Linen & 1.38 & $10-65$ & $5-38$ & $1.2-3$ & $343-1035$ & $50-70$ & - \\
\hline Sisal & 1.20 & $0.8-8$ & $7-47$ & $1.9-3$ & $507-855$ & $9-22$ & $50-73$ \\
\hline Ramie & 1.44 & $40-250$ & $18-80$ & $2-4$ & $400-938$ & $61.4-128$ & $68.6-76.2$ \\
\hline Hemp & 1.35 & $5-55$ & $10-51$ & $1.6-4.5$ & $580-1110$ & $30-60$ & $30-77$ \\
\hline Coir & 1.20 & $0.3-3$ & $7-30$ & $15-25$ & 175 & 6 & $15-51.4$ \\
\hline Kenaf & 1.20 & $1.4-11$ & $12-36$ & $2.7-6.9$ & 295-930 & $22-60$ & $45-57$ \\
\hline Banana & 1.50 & $0.4-0.9$ & $12-30$ & $5-6$ & $529-914$ & $27-32$ & 63 \\
\hline Curauá & 0.20 & 1500 & 97 & $4.5-6$ & $1250-3000$ & $30-80$ & $70-73$ \\
\hline Pineapple & 1.50 & $1-8$ & $8-41$ & $1-3$ & $170-1627$ & $60-82$ & 81 \\
\hline Abaca & 1.50 & $4.6-5.2$ & $10-30$ & 2.9 & $430-813$ & $31.1-33.6$ & $56-63$ \\
\hline Bamboo & $0.6-1.1$ & $1.5-4$ & $88-25$ & $1.3-8$ & $140-441$ & $11-36$ & 74 \\
\hline Nettle & 1.51 & 5.5 & $20-80$ & 1.7 & 650 & 38 & $53-73$ \\
\hline Flax & 1.5 & $5-900$ & - & $2-4$ & $300-800$ & $30-60$ & $30-77$ \\
\hline Palm & $0.7-1.5$ & $0.59-142$ & $150-500$ & $17-25$ & $150-500$ & 3.24 & 30 \\
\hline Softwood & 1.5 & $2.8-4.1$ & $28-47$ & - & 1000 & $18-40$ & - \\
\hline Hardwood & 1.2 & $2.67-3.98$ & 31 & - & - & 37.9 & - \\
\hline Kapok & $0.31-0.38$ & $20-32$ & 20 & 1.2 & 93.3 & 4 & - \\
\hline
\end{tabular}

\subsection{Surface Treatment of Natural Fibers}

Surface treatment of natural fibers is usually performed to enhance the properties of natural fibers, before using them to manufacture a composite material. Fiber surface modification can improve the fiber-matrix interfacial bonding, roughness, wettability and also decrease the moisture absorption of the fibers [33-42]. As a result, better mechanical properties of the resulting composites can be achieved. In this work, the focus will be on natural fibers, since the treatment suffered by the fiber improves the performance of the hybrid composites. The main surface modification methods used for natural fibers (i.e., physical and chemical) are briefly presented in this section.

\subsubsection{Physical Treatment Modifications}

The main physical treatments used to modify the surface of natural fibers are as follows: plasma, corona, ultraviolet (UV), heat treatments, electron radiation and fiber beating [15,42-44]. These treatments improve the adhesion between the fiber and matrix by changing the surface proprieties of the fibers without changing their structural composition [7,36]. However, physical treatments are more expensive compared to chemical ones, mainly because of the equipment involved in the surface modification processes [7,15]. The principal effects of physical treatments on the natural fibers are summarised in Tab. 2.

\subsubsection{Chemical Treatments}

Chemical treatments are a common way of increasing the interface adhesion between the fiber-matrix by chemical bonding or mechanical interlocking at the interface and decreases the water absorption of the fibers $[8,25]$. This is achieved by using compounds that promote adhesion by chemically coupling the fibers to the matrix, such as: sodium hydroxide [25,45-52], silane [8,23,29], acetic acid [36,42,43,53], Benzoyl Chloride [43,54,55], maleated coupling agents [39,42,43], isocyanates [4,8], peroxide [31,56,57], stearic acid [58], etc. It was shown in the literature that the fiber modification approaches have different levels of efficacy. 
In general, chemical approaches provide better improvements in properties compared to physical approaches. The improvement in mechanical and thermal properties depends on concentration of the chemical used and exposure time. Combination of treatments with two different chemicals presented better mechanical and thermal properties than the individual treatments in some cases.

Table 2: Principal physical treatments used to modify the surface of natural fibers

\begin{tabular}{|c|c|c|}
\hline $\begin{array}{l}\text { Surface } \\
\text { treatment }\end{array}$ & Treatment effect & References \\
\hline Plasma & $\begin{array}{l}\text { Plasma treatment promotes the removal of contaminants from the fiber surface } \\
\text { through ionising gases. Furthermore, this treatment improves the surface } \\
\text { roughness by increasing interfacial adhesion between the fiber-matrix. }\end{array}$ & {$[4,42]$} \\
\hline Corona & $\begin{array}{l}\text { Corona treatment promotes surface fiber change by oxidation process and } \\
\text { introduction of polar groups, which results in cleaning of the fiber surface and } \\
\text { improving the interfacial adhesion between the fiber (hydrophilic) and matrix } \\
\text { (hydrophobic). }\end{array}$ & {$[39,43]$} \\
\hline $\begin{array}{l}\text { Ultraviolet } \\
\text { (UV) }\end{array}$ & $\begin{array}{l}\text { UV treatment affects the polarity of the fiber improving wettability and } \\
\text { adhesion between the matrix-fiber. In addition, several bonds are broken (C-C, } \\
\mathrm{C}-\mathrm{O}, \mathrm{C}-\mathrm{F}, \mathrm{C}-\mathrm{Si} \text { and } \mathrm{C}-\mathrm{H}) \text { promoting the cleaning of the fibers. }\end{array}$ & {$[8,36]$} \\
\hline Ultrasound & $\begin{array}{l}\text { Ultrasound process promotes the cleaning of the surface of natural fibers in two } \\
\text { ways: micro-jetting and micro-streaming. }\end{array}$ & {$[43]$} \\
\hline Thermal & $\begin{array}{l}\text { Thermal treatment heats the fiber between } 100-200^{\circ} \mathrm{C} \text {, affecting their physical } \\
\text { and chemical property, cellulose crystallinity, decrease the water percentage } \\
\text { and low temperature constituents. }\end{array}$ & {$[8,36]$} \\
\hline
\end{tabular}

Natural fibers that undergo chemical and physical surface modifications presented improved fiber-matrix interfacial adhesion, improved fiber roughness and wettability. In addition, most of the treatments help to minimise the hydrophilic nature and decrease the moisture absorption of natural fibers. The selection of the appropriate fiber modification technique will depend on the particular fiber/matrix used and the composite end-use application. It is essential to understand the interfacial properties and bonding mechanisms of fiber-matrix and this involves significant research efforts in order to maximise NFRCs and hybrid composite applications.

Tab. 3 presents the most common chemical treatments used to treat/modify the surface of natural fibers.

Table 3: Effect of chemical treatment of natural fibers

\begin{tabular}{|c|c|c|}
\hline $\begin{array}{l}\text { Chemical } \\
\text { treatment }\end{array}$ & Treatment effect & References \\
\hline Alkaline & $\begin{array}{l}\text { Alkalisation or mercerisation treatment promotes cleaning of impurities, } \\
\text { decreases hydrophilicity and fiber constituents. The treatment reduces the } \\
\text { diameter and enhances the surface roughness of the fiber and increase the } \\
\text { interfacial adhesion of the fiber-matrix. }\end{array}$ & {$[4,38,59]$} \\
\hline Silane & $\begin{array}{l}\text { Silane treatment promotes micropore coating on the natural fiber surface. } \\
\text { Improves fiber-matrix interfacial adhesion. Pre-treatments are performed, } \\
\text { mainly alkalisation, for cleaning existing constituents. }\end{array}$ & {$[8,23,29]$} \\
\hline
\end{tabular}




\begin{tabular}{lll}
\hline \multicolumn{1}{c}{ Table 3 (continued). } & & References \\
\hline $\begin{array}{l}\text { Chemical } \\
\text { treatment }\end{array}$ & Treatment effect & \\
\hline Acetylation & $\begin{array}{l}\text { Acetylation treatment uses acid catalysts (acetic anhydride and acetic } \\
\text { acid) for the superficial plasticisation of the natural fiber, increasing } \\
\text { interfacial bonding. }\end{array}$ \\
Benzoylation & $\begin{array}{l}\text { Benzoylation treatment decreases the hydrophilicity of the natural fiber. } \\
\text { Benzoyl Chloride is used to improve the interfacial adhesion between the }\end{array}$ \\
& $\begin{array}{l}\text { fiber-matrix and the thermal stability of the fibers. Alkalisation pre- } \\
\text { treatment is performed to activate the hydroxyl groups of the fiber. }\end{array}$ \\
Maleated & $\begin{array}{l}\text { This treatment is used to modify the fiber surface and matrix with the } \\
\text { addition of a coupling agent. The maleic anhydride is grafted onto the } \\
\text { polymers to increase the compatibility between the matrix and the } \\
\text { coupling agent. } \\
\text { Isocyanate }\end{array}$ & $\begin{array}{l}\text { The treatment is used as a coupling agent in natural fibers, where it can } \\
\text { react with the hydroxyl groups found in the fiber, improving interfacial } \\
\text { adhesion and increasing water resistance. }\end{array}$ \\
\hline
\end{tabular}

\subsection{Type of Matrix}

The mechanical properties (e.g., tensile, flexural, and impact) of composite materials are directly related to their fiber/matrix interface, where poor adhesion between these elements will result in an inefficient dispersion of loads [1]. Therefore, choosing the correct fiber/matrix combination is fundamental to obtain good composite mechanical and thermal properties. The matrix provides resistance to mechanical and chemical abrasion of the reinforcement fibers, keeps the fibers in the desired position, and is responsible for an efficient load transfer between them [61,62]. The most common matrices used to produce hybrid natural fiber composites are polymeric (thermoset or thermoplastic) mainly because they can be processed at low temperature and are lightweight [63].

Fig. 2 presents a diagram of classification of matrices with the main polymeric matrices types used to produce composites.

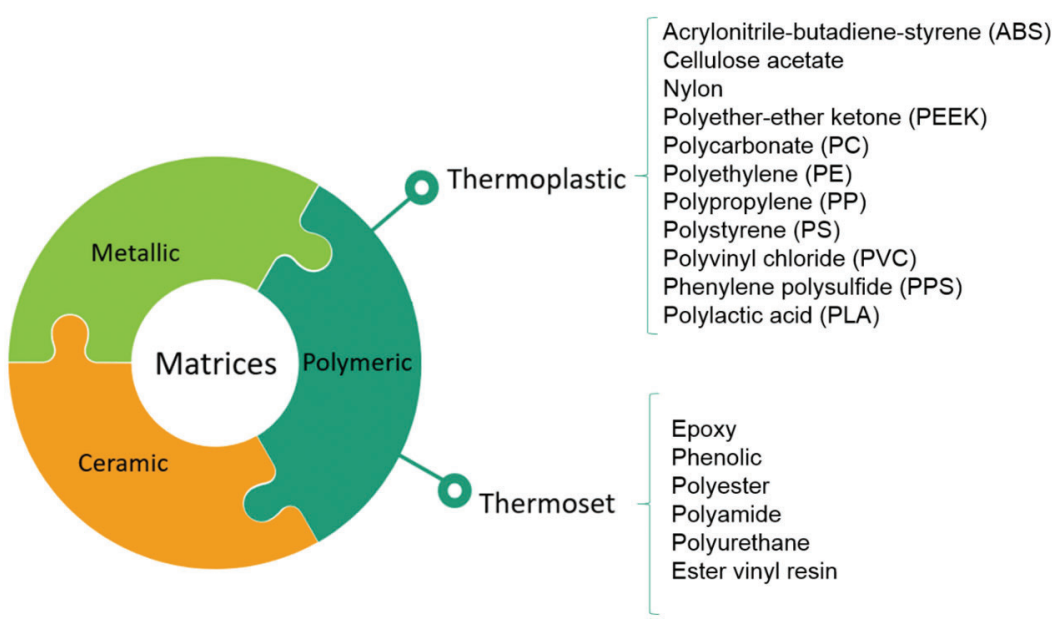

Figure 2: Schematic of classification of matrices with the main polymeric matrices types 
Thermoplastic polymer matrices can be softened, melted and, also, recycled by the application of heat. However, the continuous reprocessing of these polymers can deteriorate their mechanical and thermal properties [64]. On the other hand, the thermoset matrices (epoxy, urethane, Vinyl Ester, phenolic, polyester, polyimide, polyurethane $(\mathrm{PU})$ ) can hardly be recycled or change the shape once the polymerisation (curing) is concluded. These matrices have different chemical structures and undergo different reactivities with the surface molecules of fibers in composites [65].

The main thermoset resins used for hybrid natural composites are epoxy and unsaturated polyesters [66,67]. Epoxy resins have high mechanical strength and environmental degradation resistance. In general, epoxy resins have excellent adhesion properties, and they are easy to cure and use. In addition, no volatile agents are formed during the curing process, which is an important advantage as compared to phenolic, polyester, and vinyl ester resins. Finally, the shrinkage associated with epoxy resins is lower compared to polyesters. However, one disadvantage is that epoxy resins are relatively brittle, which is detrimental to the interlaminar properties between the matrix and the fiber reinforcement. It is known that epoxy resin cures from liquid to solid through a catalytic chemical reaction, creating extremely strong bonds that cannot be easily reversed or reformed. Because of this, the performance of this matrix material is superior to other matrices; nevertheless their recycling remains challenging. To summarise, as the majority of natural fibers become unstable at temperatures higher than $200^{\circ} \mathrm{C}$, the matrices that require high processing temperatures are not suitable to manufacture NFRCs or hybrid natural fiber composites.

\section{Mechanical Properties of Hybrid Fiber-Reinforced Composites}

Several researches were carried out in the literature to study the mechanical properties of hybrid composites reinforced with several types of natural fibers (i.e., sisal, jute, curauá, ramie, banana, etc.) or natural fibers combined with synthetic fibers [2,20,23,59,60,66,68-84]. The main objective of hybridisation is to balance the deficiency of one specific fiber to achieve sustainability, low cost, and improved performance of the material [2]. Generally, natural hybrid composites are produced by hybridising natural fibers with another either natural or synthetic fiber with superior properties (i.e., higher mechanical strength, chemical stability, nontoxicity, resistance to high temperatures, and thermal or acoustic insulation). Hybridisation of natural fibers with synthetic fibers (i.e., glass, carbon, Kevlar, basalt fibers) can significantly improve the mechanical performance of NFRCs and also their water resistance [20,71]. The glass fiber is the most used fiber in the hybridisation of NFRCs. Carbon and aramid fibers are also used in NFRC hybridisation but are limited by their high cost and difficult recyclability, thus reducing the main advantage of the hybrid NFRCs (sustainability). Furthermore, the carbon fiber provides stability and high mechanical properties to the hybrid composites but at a much higher cost [85]. For Kevlar, the main use found in literature is for higher impact resistance and in this case, the hybridisation is focused in reducing the number of aramid layers with minimal loss in impact resistance [86]. Finally, another common approach is the substitution of synthetic fibers with natural fibers. This is done with the increase of natural fiber fraction in the hybrid composite. The main purpose is to reduce costs and environmental impact of the composite, while minimizing mechanical property losses [85-87]. Hybrid composites of natural fibers with other natural fibers might not show comparable mechanical enhancements as those hybridised with synthetic fibers, but the natural-natural fibers hybrid composites will be superior in terms of sustainability.

The mechanical properties of fiber reinforced composites are mainly affected by fiber content and orientation [88], stacking sequence [86,89,90], hybrid ratio and the fiber-matrix interfacial strength $[1-2,36]$. For example, the tensile strength of hybrid composites is largely dominated by the reinforcing fiber properties, where the failure begins with the fiber with lower elongation. Considering iso-static loading of all fibers in the hybrid composite the fibers with lower strain at failure will fail first. This results in the failed fibers not participating in carrying the load. Therefore, the fibers with higher 
elongation will have to carry the brunt of the load. Consequently, the composite should present a compromise between the high and low strain fibers [1,2]. Fig. 3 shows the hybrid effect of a 50:50 wt\% LE/HE fiber composite (the hybrid effect is the apparent failure strain enhancement of the LE fiber in a hybrid composite compared to the failure strain of a LE fiber-reinforced non-hybrid composite).

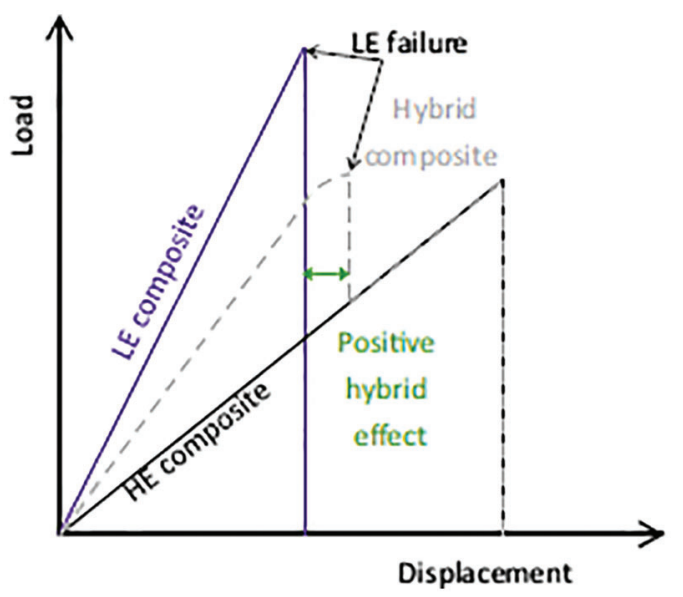

Figure 3: Illustration of the hybrid effect (the apparent failure strain enhancement of the LE fibers, under the assumption that relative volume fraction is 50/50 and that the hybrid composite is twice as thick as the reference composites: LE-low elongations; HE-High elongation). Reproduced with permission from [2]

The volume fraction of each type of fibers has an impact in how the failure will occur. For composites with high strain fiber volume, these fibers will dominate the stress distribution. The resulting stress/strain curve will present a higher secondary peak. If the fiber fraction is reversed, the composite's strength will be limited by the low strain fiber [2]. Another factor that can affect the mechanical properties of hybrid composites is the weight ratio, also known as volume or weight fraction of the reinforcing fiber constituents [1]. By varying the weight ratio/volume of the fibers it is possible to change the composites overall mechanical properties. Therefore, depending on the application requirements the hybridisation method provides flexibility in fiber selection for achieving the desired materials properties.

For the flexural properties the stacking sequence of the hybrid composite is highly relevant [91,92]. The tensile and compressive stresses are maximum in the bottom and top faces of a specimen under 3-point bending flexural load, respectively and they linearly decrease towards the neutral line (middle of the specimen). As such the fibers with higher mechanical properties should be placed in the outward most lamina in a composite. This is especially interesting when using synthetic/natural hybrid composites, since most synthetic fibers also present a hydrophobic characteristic, and thus will reduce water absorption [78,93]. The impact properties of natural hybrid composites was found to vary greatly in the literature. The impact resistance of hybrid composites is strongly linked to the fiber mechanical properties [94,95], layer stacking sequence [2] and the interfacial adhesion between the fiber and the matrix [23]. Some authors found that the stacking sequence has an insignificant effect on the impact strength, while the fiber orientation in the hybrid composite has a noticeable effect on the impact strength [91].

Tab. 4 summarises some recent studies on the effect of hybridisation on the mechanical properties of hybrid composites. 
JRM, 2022, vol.10, no.3

Table 4: Effect of hybridisation on the mechanical properties of hybrid composites

\begin{tabular}{|c|c|c|c|}
\hline $\begin{array}{l}\text { Composite (type of fiber } \\
\text { and matrix) }\end{array}$ & Fabrication technique and test method & Mechanical properties & References \\
\hline $\begin{array}{l}\text { Sisal/jute/glass } \\
\text { (Polyester-methyl ethyl } \\
\text { ketone) }\end{array}$ & $\begin{array}{l}\text { Hand-lay-up with compression moulding in a } \\
\text { hydraulic press. Tensile, flexural, impact and } \\
\text { interfacial shear strength tests }\end{array}$ & $\begin{array}{l}\text { The } 20 \% \text { sisal, } 20 \% \text { jute and } 60 \% \text { of glass-fiber } \\
\text { presented the best performance in tensile, flexural and } \\
\text { impact properties when compared to the other hybrid } \\
\text { composites. }\end{array}$ & [88] \\
\hline $\begin{array}{l}\text { Banana/glass/sisal } \\
\text { (Epoxy resin-LY556) }\end{array}$ & $\begin{array}{l}\text { Compression moulding. Tensile, flexural and } \\
\text { impact tests }\end{array}$ & $\begin{array}{l}\text { The hybrid banana/sisal/glass fiber composite presented } \\
\text { highest tensile strength (glass fiber on the outer layers } \\
\text { and in the middle). For flexural strength, the best } \\
\text { configuration was found for the banana/sisal composite } \\
\text { as a sandwich between layers of glass fiber. }\end{array}$ & {$[96]$} \\
\hline $\begin{array}{l}\text { Sisal/cotton (Isophthalic } \\
\text { polyester) }\end{array}$ & Hand-lay-up. Tensile, flexural and impact tests & $\begin{array}{l}\text { The optimal composite presented a percentage of } 40 \% \text { of } \\
\text { cotton/sisal reinforcement. Sisal aligned in the load } \\
\text { application direction presented better results when } \\
\text { compared with the cotton ones. }\end{array}$ & [69] \\
\hline Flax/glass (Phenolic) & $\begin{array}{l}\text { Compression moulding. Tensile, mode I } \\
\text { fracture toughness and short beam tests }\end{array}$ & $\begin{array}{l}\text { For the mode I fracture toughness and the interlaminar } \\
\text { shear strength the hybrid composites with higher flax } \\
\text { content presented better results when compared with } \\
\text { pure glass fiber composites. }\end{array}$ & [58] \\
\hline $\begin{array}{l}\text { Banana/Kenaf } \\
\text { (Unsaturated polyester) }\end{array}$ & Hand-lay-up. Tensile, flexural and impact tests & $\begin{array}{l}\text { The hybridisation process increased the mechanical } \\
\text { properties of the single banana and kenaf composites. } \\
\text { The superficial treatments improved the tensile, flexural } \\
\text { and impact strengths around } 10 \% \text { of the hybrid } \\
\text { composites when compared with the untreated condition. }\end{array}$ & {$[59]$} \\
\hline $\begin{array}{l}\text { Twisted kenaf/neem/ } \\
\text { glass fibers (Epoxy } \\
\text { resin-LY556) }\end{array}$ & $\begin{array}{l}\text { Vacuum assisted compression moulding. } \\
\text { Tensile, flexural, impact and double shear tests. }\end{array}$ & $\begin{array}{l}\text { The glass fiber }+ \text { twisted neem (vertical) }+ \text { twisted kenaf } \\
\text { (inclined) }+ \text { twisted neem (vertical) }+ \text { glass fiber hybrid } \\
\text { composites presented the best mechanical properties } \\
\text { with a tensile ultimate strength around } 70 \mathrm{MPa} \text { and } \\
\text { absorbed impact energy equivalent to } 12 \mathrm{~J} \text {. }\end{array}$ & [97] \\
\hline Curauá/glass (Polyester) & $\begin{array}{l}\text { Compression moulding using a hydraulic } \\
\text { press. Barcol hardness and impact tests. }\end{array}$ & $\begin{array}{l}\text { The impact properties and composite hardness increased } \\
\text { in the composites with higher percentages of glass fibers, } \\
\text { due to better interfacial adhesion of these fibers with } \\
\text { polyester resins. }\end{array}$ & {$[72]$} \\
\hline Banana/jute (Epoxy) & $\begin{array}{l}\text { Hand-lay-up. Tensile, flexural, impact and } \\
\text { interfacial shear strength tests. }\end{array}$ & $\begin{array}{l}\text { The hybridisation improved the mechanical properties of } \\
\text { the studied composites, especially the impact properties. } \\
\text { The maximum value of interlaminar shear strength was } \\
\text { found for the banana/jute composite with } 30 \mathrm{wt} \% \text { of fiber } \\
\text { loading. }\end{array}$ & {$[98]$} \\
\hline $\begin{array}{l}\text { Sisal/bamboo (Polyester } \\
\text { resin-methyl ethyl } \\
\text { ketone) }\end{array}$ & Hand-lay-up. Tensile, flexural and impact tests. & $\begin{array}{l}\text { The mechanical properties of the hybrid composites } \\
\text { increased in the composites with higher weight } \\
\text { percentage of bamboo. The alkalinisation process also } \\
\text { improved the tensile strength by } 30 \% \text { and the impact } \\
\text { energy by } 40 \% \text {. }\end{array}$ & [71] \\
\hline $\begin{array}{l}\text { Echinoidea spike } \\
\text { particles and kenaf } \\
\text { (Neem oil blended } \\
\text { epoxy) }\end{array}$ & Hand-lay-up. Tensile, flexural, impact test. & $\begin{array}{l}\text { The Neem oil had little impact in the epoxy resin with a } \\
\text { slight decline in mechanical properties. The addition of } \\
\text { the kenaf fibers had a positive impact in mechanical } \\
\text { properties. The addition of the hybrid kenaf- particles } \\
\text { increased the mechanical properties of the composite. }\end{array}$ & [99] \\
\hline Flax/ $\mathrm{TiO}_{2}$ (Epoxy) & $\begin{array}{l}\text { Hand lay-up with compression moulding. } \\
\text { Tensile, flexural, impact and short beam tests } \\
\text { were carried out. }\end{array}$ & $\begin{array}{l}\text { Improvements in tensile, flexural, impact and ILSS of } \\
\text { hybrid composites were approx. } 11 \%, 20 \%, 10 \% \text { and } \\
19 \% \text { when compared to the unmodified samples. }\end{array}$ & {$[100]$} \\
\hline Jute/nano-clay (Epoxy) & $\begin{array}{l}\text { Hand lay-up followed by compression } \\
\text { moulding. Tensile, flexural, impact testing. }\end{array}$ & $\begin{array}{l}\text { The best material properties overall were found for the } \\
5 \% \mathrm{NaOH} \text {-treated jute fiber with } 5 \mathrm{wt} \% \text { nano-clay } \\
\text { content. }\end{array}$ & [101] \\
\hline
\end{tabular}




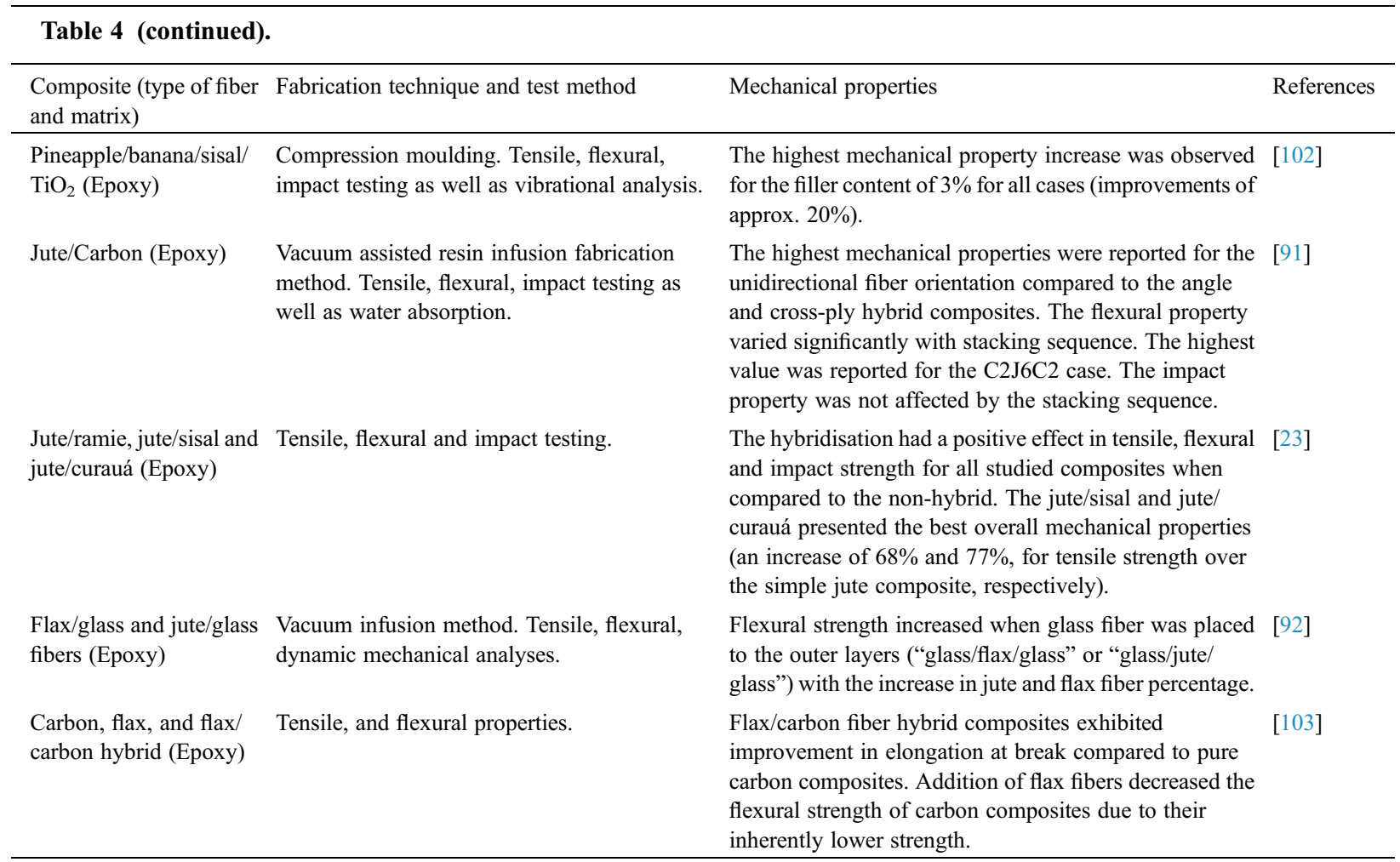

\section{Thermal Properties of Hybrid Fiber-Reinforced Composites}

The main techniques used for thermal analysis of hybrid epoxy/synthetic/natural fiber composites are as follows: Thermogravimetric Analysis (TGA), Differential Scanning Calorimetry (DSC), Thermomechanical Analysis (TMA) and Dynamic Mechanical Analysis (DMA). The main thermal properties of the composites provided by these techniques are: the crystallisation temperature $\left(T_{\mathrm{c}}\right)$, melting temperature $\left(T_{\mathrm{m}}\right)$, glass transition temperature $\left(T_{\mathrm{g}}\right)$, thermal expansion coefficient (CTE), viscoelastic behaviour and thermal stability (see Fig. 4). It was shown in the literature that several factors can affect the thermal properties of the composite materials, such as: fiber and matrix type, manufacture process, and type of loading [104-106]. In addition, the fiber orientation and volume and chemical treatment of the fibers will also impact the thermal properties of the composites [15].

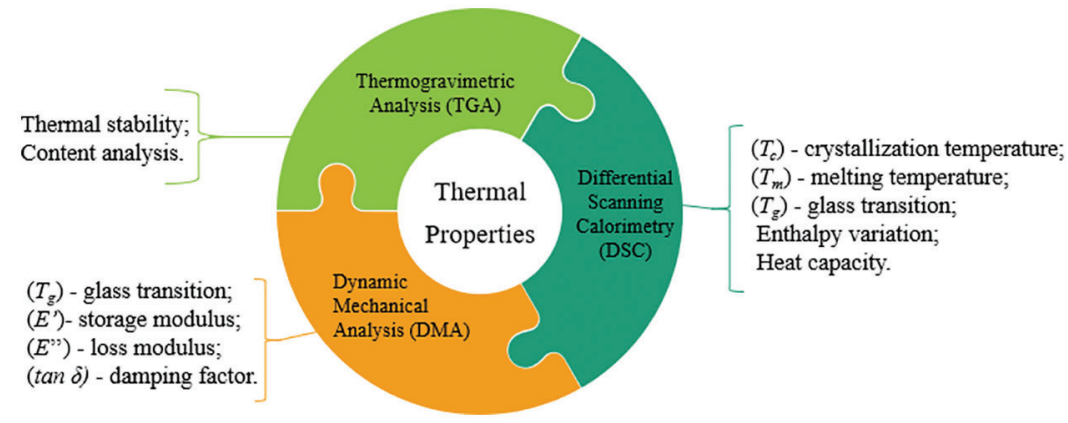

Figure 4: Schematic of the principal methods used to determine the thermal properties of composites with the main thermal properties of the bio composites provided by these techniques 
TGA analysis consists of measuring the weight of a material sample, commonly either as a function of increasing temperature, or isothermally as a function of time, in an atmosphere of nitrogen, helium, air, or other gases [107,108]. Typical thermogravimetric parameters consist of moisture, volatile substances, loss on ignition or ash. Different temperatures and measurement times are applied in accordance with the matrix type of the composite sample [107-110]. Natural fiber based composites have the thermal stability measured from the decomposition of their constituents (hemicellulose, cellulose, lignin and others) [24,53,66,111-114]. The incorporation of synthetic fibers in natural composites will increase their thermal stability and shift the degradation point of the composites to the right, decreasing its thermal degradation [115]. The thermogravimetric behaviour of hybrid synthetic/natural composites depends on composite constituents (fibers and matrix). For example, similar natural fibers such as jute, sisal, wood and cotton have similar TG/DTG curves and thermal decomposition patterns. The derivative thermogravimetric test (DTG) shows the maximum rate of peak thermal decomposition, and fiber constituents are indicated by peaks in each degradation range. Lignocellulose fibers (i.e., jute, flax, wood, sisal, ramie, curauá and others) present three stages of degradation, the first stage is related to water loss by natural fiber $\left(60^{\circ} \mathrm{C}-\right.$ $100^{\circ} \mathrm{C}$ ). The second stage is related to the loss of the main constituents of the fibers: hemicellulose, cellulose, and lignin $\left(200^{\circ} \mathrm{C}-500^{\circ} \mathrm{C}\right)$. Finally, the last stage of degradation is the formation of active coal as a form of residue [53,111-114].

The DSC determines the material transitions as a function of temperature and time. The endothermic (heat absorption) and exothermic (heat released) peaks and magnitudes indicate the thermal phase transformation of the composites [116,117]. Thermal data extracted from this analysis are: the glasstransition temperature $\left(T_{\mathrm{g}}\right)$, crystallisation temperature $\left(T_{\mathrm{c}}\right)$, fusion temperature $\left(T_{\mathrm{m}}\right)$, enthalpy variation and heat capacity [118]. The glass transition temperature $\left(T_{\mathrm{g}}\right)$ is the temperature band in which a thermoset polymer changes from rigid to a more flexible or 'rubbery' state. There are several factors that can affect the data collected by the DSC analysis, such as: sample size and shape, heat ramp and type of atmosphere. Several authors used the DSC technique to investigate the effect of hybridisation on the glass transition and the peaks (endothermic and exothermic) of hybrid epoxy/synthetic/natural composites [66,87,119-121].

The following data can be extracted from DMA: storage modulus $\left(E^{\prime}\right)$, loss modulus $\left(E^{\prime \prime}\right)$, damping factor $\left(\tan \delta=\mathrm{E}^{\prime \prime} / \mathrm{E}^{\prime}\right)$ and glass transition temperature $\left(T_{\mathrm{g}}\right)$ [118]. The storage modulus $\left(E^{\prime}\right)$ is associated with the energy storage of the elastic characteristics of the material [24,105,122]. It decreases with increase in temperature and is associated with "stiffness" of the composites sample [105,122]. The loss modulus $\left(E^{\prime \prime}\right)$ is associated with the energy dissipation promoted by the viscous part of the composite sample. This dissipation is related to the internal molecular friction of the molecular chains due to the following factors: morphological transformation and relaxation, morphology, and system heterogeneity $[105,108]$. The damping factor is defined by dividing the storage and loss modulus (tan $\left.\delta=E^{\prime \prime} / E^{\prime}\right)$ and is associated with the internal mobility of the polymeric molecular chains, showing the influence of the fiber/matrix interactions $[24,105,123]$. A high $\tan \delta$ value shows that the system is dissipating more energy than it is storing due to fiber/matrix interaction quality, while a low $\tan \delta$ value shows that the polymeric chain has lower mobility indicating a good fiber/matrix interfacial interaction. To determine $T_{\mathrm{g}}$ using DMA, measurements of the complex modulus are typically made as temperature is increased at a constant heating rate. The thermal properties of the composites obtained from DMA depends on the physical or structural arrangement of phases such as interface, morphology and the nature of composite constituents. It was shown in the literature that the presence of additive fillers, fiber content, fiber orientation, the chemical treatment of the fibers and the mode of testing governed the dynamic mechanical properties of a composite material $[105,124]$. Several researchers used the DMA tests to study the influence of hybridisation on the thermal properties of the hybrid composites [24,92,119,125-129]. 
Tab. 5 summarises several recent studies on the effect of hybridisation on the thermal properties of hybrid composites.

Table 5: Effect of hybridisation on the thermal properties of hybrid composites obtained from TGA, DSC and DMA analysis

\begin{tabular}{|c|c|c|c|}
\hline Composite & Method and parameters & Effect hybridisation on the thermal properties & References \\
\hline $\begin{array}{l}\text { Sugar palm/ } \\
\text { Glass (Polyester) }\end{array}$ & $\begin{array}{l}\text { TGA-The temperature was ramped from } 30^{\circ} \mathrm{C} \text { to } \\
600^{\circ} \mathrm{C} \text { with a heating rate of } 20^{\circ} \mathrm{C} / \mathrm{min} \text {, under a } \\
\text { Nitrogen Atmosphere with } 50 \mathrm{~mL} / \mathrm{min} \text {. The } \\
\text { equipment used the GA Q } 500 \text { from TA } \\
\text { Instruments. } \\
\text { DMA-Three-point Bending Test with frequency of } \\
1 \mathrm{~Hz} \text {. Equipment (DMA Q } 800 \text { of TA Instruments). } \\
\text { The temperature was ramped from } 30 \text { to } 150^{\circ} \mathrm{C} \\
\text { with a heating rate of } 5{ }^{\circ} \mathrm{C} / \mathrm{min} \text {. Rectangular } \\
\text { specimens having size } 60 \mathrm{~mm} \times 10 \mathrm{~mm} \times 3 \mathrm{~mm} \\
\text { were used. }\end{array}$ & $\begin{array}{l}\text { TGA-the increase in fiberglass decreased the } \\
\text { residue percentage. } \\
\text { DMA-the hybridisation and the chemical } \\
\text { treatment provided a higher storage and loss } \\
\text { modulus, but smaller tan } \delta \text {. }\end{array}$ & [130] \\
\hline $\begin{array}{l}\text { Cotton/Glass } \\
\text { (Polyester) }\end{array}$ & $\begin{array}{l}\text { DMA-Three-point Bending Test with Frequency of } \\
1 \mathrm{~Hz} \text { an Oscillation amplitude of } 15 \mu \mathrm{m} \text {. Equipment } \\
\text { used DMA } 2980 \text { Dynamic Mechanical Analyser. } \\
\text { The temperature was ramped from room to } 180^{\circ} \mathrm{C} \\
\text { with a heating rate of } 3{ }^{\circ} \mathrm{C} / \mathrm{min} \text {. Rectangular } \\
\text { specimens having size } 60 \mathrm{~mm} \times 10 \mathrm{~mm} \times 3 \mathrm{~mm} \\
\text { were used. }\end{array}$ & $\begin{array}{l}\text { DMA }-T_{g} \text { of hybrid composites increased } \\
\text { compared to synthetic and natural fiber pure } \\
\text { composite. }\end{array}$ & {$[131]$} \\
\hline $\begin{array}{l}\text { Bamboo/Kenaf } \\
\text { (Epoxy) }\end{array}$ & $\begin{array}{l}\text { TMA-Expansion or Compression test with } \\
\text { minimal force of } 0.02 \mathrm{~N} \text {. The temperature was } \\
\text { ramped }-30^{\circ} \mathrm{C} \text { to } 100^{\circ} \mathrm{C} \text { with a heating rate of } \\
5^{\circ} \mathrm{C} / \text { min. } \\
\text { DMA-Three-point bending Test with frequency of } \\
1 \mathrm{~Hz} \text { an oscillation amplitude of } 10 \mu \mathrm{m} \text { and } \\
\text { constant current force of } 3 \mathrm{~N} \text {. Rectangular } \\
\text { specimens having size } 45 \mathrm{~mm} \times 10 \mathrm{~mm} \times 3 \mathrm{~mm} \\
\text { were used. The temperature was ramped from } 25^{\circ} \mathrm{C} \\
\text { to } 180^{\circ} \mathrm{C} \text { with a heating rate of } 5^{\circ} \mathrm{C} / \mathrm{min} \text {. }\end{array}$ & $\begin{array}{l}\text { TMA/DMA The expansion coefficient of the } \\
\text { hybrid composites ( } 50 \% \text { bamboo } / 50 \% \text { kenaf) was } \\
\text { lower when compared to the other cases. } T_{g} \text { and } \\
\text { storage modulus results showed an increase in } \\
\text { thermal properties. }\end{array}$ & {$[126]$} \\
\hline $\begin{array}{l}\text { Jute/oil palm } \\
\text { (Epoxy) }\end{array}$ & $\begin{array}{l}\text { TGA-The temperature was ramped from } 30^{\circ} \mathrm{C} \text { to } \\
900^{\circ} \mathrm{C} \text { with a heating rate of } 20^{\circ} \mathrm{C} / \mathrm{min} \text {, under a } \\
\text { Nitrogen Atmosphere. Perkin Elmer thermal } \\
\text { gravimetric analyser. }\end{array}$ & $\begin{array}{l}\text { TGA-The increase of percentage of jute fiber } \\
\text { improved the thermal stability of the composite. }\end{array}$ & [113] \\
\hline $\begin{array}{l}\text { Jute/Coir (Epoxy } \\
\text { Novolac) }\end{array}$ & $\begin{array}{l}\text { TGA-The temperature was ramped from } 30^{\circ} \mathrm{C} \text { to } \\
700^{\circ} \mathrm{C} \text { with a heating rate of } 10^{\circ} \mathrm{C} / \mathrm{min} \text {, under a } \\
\text { Nitrogen Atmosphere with } 30 \mathrm{~mL} / \mathrm{min} \text {. Equipment } \\
\text { DTG-60 (Schimadzu). } \\
\text { DSC-The temperature was ramped from } 20^{\circ} \mathrm{C} \text { to } \\
400^{\circ} \mathrm{C} \text { with a heating rate of } 10^{\circ} \mathrm{C} / \mathrm{min} \text {, under a } \\
\text { Nitrogen Atmosphere with } 50 \mathrm{~mL} / \mathrm{min} \text {. Equipment } \\
\text { DSC Q10 (TA Instruments). } \\
\text { DMA-Three-point bending Test with frequency of } \\
10 \mathrm{~Hz} \text {. Rectangular specimens having size } 60 \\
\text { mm } \times 10 \mathrm{~mm} \times 3 \mathrm{~mm} \text { were used. The temperature } \\
\text { was ramped from } 30^{\circ} \mathrm{C} \text { to } 200^{\circ} \mathrm{C} \text { with a heating rate } \\
\text { of } 5{ }^{\circ} \mathrm{C} / \mathrm{min} \text {. Equipment DMA Q } 800 \text {, TA. }\end{array}$ & $\begin{array}{l}\text { TGA-The increase in coir fiber percentage } \\
\text { increased the onset of degradation temperature of } \\
\text { the hybrid composite. } \\
\text { DSC-Hybrid composites presented higher } \\
\text { enthalpy values than the pure resin. } \\
\text { DMA-The hybrid composite ( } 50 \% \text { Jute fiber } / 50 \% \\
\text { coir fiber) presented the largest storage modulus } \\
\text { and the lowest tan } \delta \text { when compared to the other } \\
\text { hybrid composites. }\end{array}$ & [132] \\
\hline
\end{tabular}


Table 5 (continued).

\begin{tabular}{|c|c|c|c|}
\hline Composite & Method and parameters & Effect hybridisation on the thermal properties & References \\
\hline $\begin{array}{l}\text { Cocos nucifera } \\
\text { sheath (CNS) } \\
\text { /Kevlar (Epoxy) }\end{array}$ & $\begin{array}{l}\text { TGA-The temperature was ramped from } 30^{\circ} \mathrm{C} \text { to } \\
900^{\circ} \mathrm{C} \text { with a heating rate of } 10^{\circ} \mathrm{C} / \mathrm{min} \text {, under a } \\
\text { Nitrogen Atmosphere with } 50 \mathrm{~mL} / \mathrm{min} \text {. Equipment } \\
\text { Mettler Toledo DSC. } \\
\text { DSC-The temperature was ramped from } 30^{\circ} \mathrm{C} \text { to } \\
900^{\circ} \mathrm{C} \text { with a heating rate of } 10^{\circ} \mathrm{C} / \mathrm{min} \text {, under a } \\
\text { Nitrogen Atmosphere. Equipment Mettler Toledo } \\
\text { DSC. } \\
\text { DMA-Three-point bending test with frequency of } \\
1 \mathrm{~Hz} \text {. Rectangular specimens having size } 60 \mathrm{~mm} \times \\
12.5 \mathrm{~mm} \times 3 \mathrm{~mm} \text {. The temperature was ramped } \\
\text { from room temperature to } 200^{\circ} \mathrm{C} \text { with a heating rate } \\
\text { of } 10^{\circ} \mathrm{C} / \mathrm{min} \text {. Equipment DMA Q800, TA. }\end{array}$ & $\begin{array}{l}\text { TGA-The } 75 \% \mathrm{G} / 25 \% \mathrm{CNS} \text { hybrid presented the } \\
\text { highest thermal stability when compared to the } \\
\text { other hybrid composites. } \\
\text { DSC-The DSC results were similar to the TGA. } \\
\text { The } 75 \% \mathrm{G} / 25 \% \mathrm{CNS} \text { hybrid composites } \\
\text { presented lower endothermal peaks when } \\
\text { compared to the other studied hybrid composites. } \\
\text { DMA-Hybridisation with } 25 \% \mathrm{CNS} / 75 \% \mathrm{~K} \\
\text { presented superior storage modulus value when } \\
\text { compared to pure Kevlar composite. }\end{array}$ & {$[87]$} \\
\hline $\begin{array}{l}\text { Sugar Palm/ } \\
\text { Glass (Epoxy) }\end{array}$ & $\begin{array}{l}\text { DMA-Dual Cantilever Test with Oscillatory } \\
\text { frequency of } 1 \mathrm{~Hz} \text {. Equipment used DMA } \\
\text { Instrument Q800 V20.24 Build } 43 \text { Module DMA } \\
\text { Multi-Frequency. The temperature was ramped } \\
\text { from } 25^{\circ} \mathrm{C} \text { to } 150^{\circ} \mathrm{C} \text { with a heating rate of } 5{ }^{\circ} \mathrm{C} / \\
\text { min. }\end{array}$ & $\begin{array}{l}\text { DMA-The hybridisation and Benzoyl treatment } \\
\text { increased the storage and loss modulus of the } \\
\text { composites. }\end{array}$ & [133] \\
\hline $\begin{array}{l}\text { Banana/PALF/ } \\
\text { Glass (Epoxy) }\end{array}$ & $\begin{array}{l}\text { TGA-The temperature was ramped from } 30^{\circ} \mathrm{C} \text { to } \\
600^{\circ} \mathrm{C} \text { with a heating rate of } 10^{\circ} \mathrm{C} / \mathrm{min} \text {, under a } \\
\text { Nitrogen Atmosphere at a flow rate of } 20 \mathrm{~mL} / \mathrm{min} \text {. } \\
\text { Samples of around } 4.9-8.9 \mathrm{mg} \text {. The equipment } \\
\text { used was TA TGA Q } 500 \text {. } \\
\text { DMA-Three-point Bending Test with Frequency of } \\
1 \mathrm{~Hz} \text {. The temperature was ramped from } 0-160^{\circ} \mathrm{C} \\
\text { with a heating rate of } 3{ }^{\circ} \mathrm{C} / \mathrm{min} \text {. }\end{array}$ & $\begin{array}{l}\text { TGA-The group with fiber percentage of } 40 \% \\
\text { presented the best thermal stability within the } \\
\text { studied composites. } \\
\text { DMA-The } 30 \mathrm{wt} \% \text { banana-glass fiber hybrid } \\
\text { composite presented the highest } T_{g} \text { when } \\
\text { compared to the other cases studied. }\end{array}$ & [134] \\
\hline $\begin{array}{l}\text { Sisal/Glass } \\
\text { (Epoxy) }\end{array}$ & $\begin{array}{l}\text { TGA-The temperature was ramped from } 30^{\circ} \mathrm{C} \text { to } \\
600^{\circ} \mathrm{C} \text { with a heating rate of } 10^{\circ} \mathrm{C} / \mathrm{min} \text {, under a } \\
\text { Nitrogen Atmosphere. Samples of approx. } 20 \mathrm{mg} \text {. } \\
\text { The equipment used was NETZSCH TG } \\
209 \mathrm{~F} 3 \text { Tarsus. } \\
\text { DSC-The temperature was ramped from } 30^{\circ} \mathrm{C} \text { to } \\
500^{\circ} \mathrm{C} \text { with a heating rate of } 20^{\circ} \mathrm{C} / \mathrm{min} \text {, under a } \\
\text { Nitrogen Atmosphere at a flow rate of } 50 \mathrm{~mL} / \mathrm{min} \text {. } \\
\text { Samples of around } 20 \mathrm{mg} \text {. The equipment used was } \\
\text { NETZSCH DSC } 00 \mathrm{~F} 3 \text { Maia. }\end{array}$ & $\begin{array}{l}\text { TGA-The hybridisation increased the thermal } \\
\text { stability when compared to the pure sisal. } \\
\text { DSC-The natural/synthetic hybrid composite } \\
\text { presented the lowest endothermic peak when } \\
\text { compared to the other hybrid composites studied. }\end{array}$ & {$[66]$} \\
\hline $\begin{array}{l}\text { Kenaf/Pineapple } \\
\text { leaf (Phenolic) }\end{array}$ & $\begin{array}{l}\text { TGA-The temperature was ramped from } 30^{\circ} \mathrm{C} \text { to } \\
700^{\circ} \mathrm{C} \text { with a heating rate of } 20^{\circ} \mathrm{C} / \mathrm{min} \text {, under a } \\
\text { Nitrogen Atmosphere. The equipment used was } \\
\text { TGA Q } 500 \text { TA Instrument. } \\
\text { TMA-The temperature was ramped from } 30^{\circ} \mathrm{C} \text { to } \\
200^{\circ} \mathrm{C} \text { with a heating rate of } 5{ }^{\circ} \mathrm{C} / \mathrm{min} \text {, under a } \\
\text { Nitrogen Atmosphere. Square specimens having } \\
\text { size } 5 \mathrm{~mm} \times 5 \mathrm{~mm} \times 3 \mathrm{~mm}^{3} \text { The equipment used } \\
\text { was TA Instrument Q } 400 \text {. } \\
\text { DMA-Three-point Bending Test. The temperature } \\
\text { was ramped from } 30-150^{\circ} \mathrm{C} \text { with a heating rate of } 5 \\
{ }^{\circ} \mathrm{C} / \text { min. The equipment used was TA DMA Q800. }\end{array}$ & $\begin{array}{l}\text { TGA-Hybridisation decreased the onset of } \\
\text { degradation temperature of the composites. } \\
\text { TMA-the composite with } 30 \% \text { Pineapple and } \\
70 \% \text { Kenaf showed high thermal resistance. } \\
\text { DMA-The composite with } 30 \% \text { Pineapple and } \\
\text { 70\% Kenaf showed an increase in storage } \\
\text { modulus. }\end{array}$ & [108] \\
\hline
\end{tabular}


Table 5 (continued).

\begin{tabular}{|c|c|c|c|}
\hline Composite & Method and parameters & Effect hybridisation on the thermal properties & References \\
\hline $\begin{array}{l}\text { Jute/Sisal } \\
\text { (Epoxy) }\end{array}$ & $\begin{array}{l}\text { TGA-The temperature was ramped from } 30^{\circ} \mathrm{C} \text { to } \\
800^{\circ} \mathrm{C} \text { with a heating rate of } 10^{\circ} \mathrm{C} / \mathrm{min} \text {, under a } \\
\text { Nitrogen Atmosphere with } 20 \mathrm{~mL} / \mathrm{min} \text {. Samples of } \\
\text { around } 15-25 \mathrm{mg} \text {. Equipment Perkin Elmer TGA } \\
4000 \text {. } \\
\text { DSC-The temperature was ramped from } 30^{\circ} \mathrm{C} \text { to } \\
400^{\circ} \mathrm{C} \text { with a heating rate of } 10^{\circ} \mathrm{C} / \mathrm{min} \text {, under a } \\
\text { Nitrogen Atmosphere at a flow rate of } 20 \mathrm{~mL} / \mathrm{min} \text {. } \\
\text { The equipment used was Perkin Elmer model DSC } \\
4000 \text {. } \\
\text { DMA-Three-point bending Test with frequency of } \\
1 \mathrm{~Hz} \text {. Rectangular specimens having size } 50 \mathrm{~mm} \times \\
13 \mathrm{~mm} \times 3 \mathrm{~mm} \text {. The temperature was ramped from } \\
30 \text { to } 200^{\circ} \mathrm{C} \text {. Equipment DMA } 6100 \text {, Seiko. }\end{array}$ & $\begin{array}{l}\text { TGA-The thermal stability augmented with the } \\
\text { hybridisation and the increase of the jute fiber. } \\
\text { DSC-All hybrid composites presented benefit in } \\
\text { properties: } T_{g}, T_{c} \text { and } T_{d} \text {. } \\
\text { DMA-The increment of jute fiber increased the } \\
\text { storage modulus, loss modulus and } T_{g} \text {, of hybrid } \\
\text { composites. }\end{array}$ & [119] \\
\hline $\begin{array}{l}\text { Jute/Carbon } \\
\text { (Epoxy) }\end{array}$ & $\begin{array}{l}\text { TGA-The temperature was ramped from } 20^{\circ} \mathrm{C} \text { to } \\
800^{\circ} \mathrm{C} \text { with a heating rate of } 20^{\circ} \mathrm{C} / \mathrm{min} \text {, under a } \\
\text { Nitrogen Atmosphere. Samples of around } 5-6 \mathrm{mg} \text {. } \\
\text { Equipment SDT Q600 Model. }\end{array}$ & $\begin{array}{l}\text { TGA-The effect of hybridisation increased the } \\
\text { onset and end of the degradation temperatures of } \\
\text { the composite. }\end{array}$ & [135] \\
\hline
\end{tabular}

To summarise, using natural fibers with low lignin content leads to better thermal performance of composites. The thermal stability of fibers can be enhanced by removing certain proportion of hemicelluloses and lignin constituents by different chemical treatments. The incorporation of synthetic fibers in natural fiber reinforced composites increases their thermal stability. The degradation of natural fibers is an important issue in the development of hybrid natural fiber reinforced composites in both manufacturing (curing, extrusion or injection moulding) and for the use of these materials in service.

\section{Water Absorption Behaviour of Hybrid Fiber-Reinforced Composites}

The affinity to absorb moisture by natural fibers and its composites, is widely known and reported in the available literature [12-13,25,66,136-138]. The absorption of moisture into a fiber-reinforced polymer composite leads to poor fiber-matrix interfacial adhesion, which will lead to an increasingly poor loadtransferring efficiency from the matrix to the reinforcement fiber. In particular, for natural fibers, there is also the aggravating factor that water uptake within the fiber leads to the degradation of its physical, thermal and mechanical properties due to the leeching of water-soluble components [139].

Moisture diffusion in polymeric composites is governed by three different mechanisms [140]. The first involves diffusion of water molecules inside the micro gaps between polymer chains. The second involves capillary transport into the gaps and flaws at the interfaces between fiber and the matrix. This is a result of poor wetting and impregnation during the initial manufacturing stage. The third involves transport from microcracks in the matrix arising from the swelling of fibers (particularly in the case of natural fiber composites) [35] (see Fig. 5). According to these mechanisms, there are three types of diffusion behaviour of polymeric composites: Fickian diffusion model, anomalous or non-Fickian, and an intermediate case between Fickian and non-Fickian [140].

It was shown in the literature that moisture diffusion in hybrid composites depends on a variety of parameters: fiber volume fraction, fiber orientation and stacking sequence, fiber nature, voids, temperature, presence of fillers, fiber surface treatments and immersion time. For instance, higher immersion times, natural fiber volume fraction and voids increase the composite moisture uptake $[13,141,142]$. As well, at higher temperature of immersion, moisture uptake behaviour is accelerated and 
the moisture saturation time is considerably shortened [1]. On the other hand, the fiber stacking sequence (e.g., placing the hydrophobic fiber fabrics on the outer layers), as well as the fiber orientation (e.g., $0^{\circ}$ orientation of the natural fiber) was shown to lower the water uptake of the composites $[143,144]$.
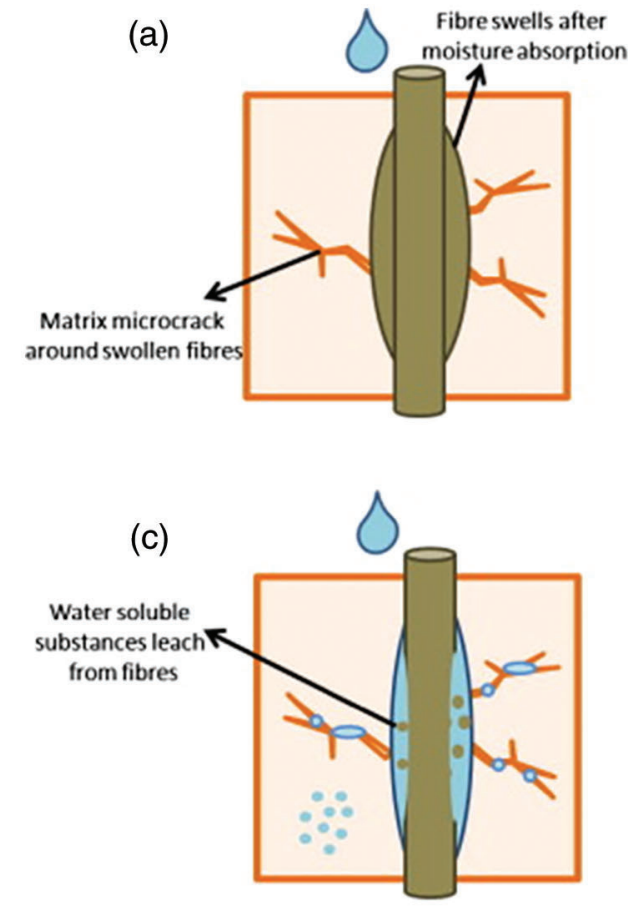

(b)

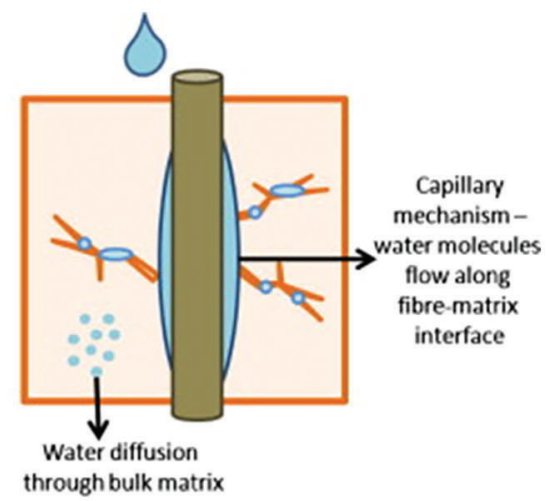

(d)

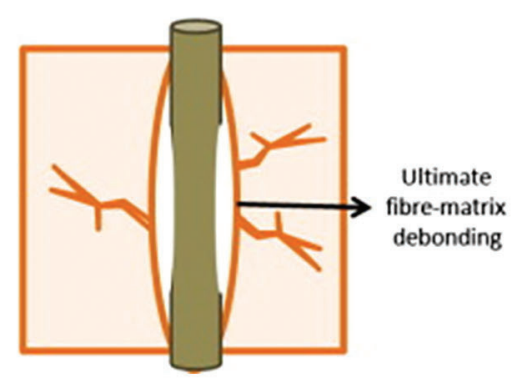

Figure 5: Effect of water on fiber-matrix interface: (a) Formation of micro-cracks due to fiber swelling; (b) water molecules diffuse in the bulk matrix and flow along the fiber-matrix interface (c) water soluble substance leaching; and (d) debonding of fiber-matrix interface. Reproduced with permission from [35]

One solution to reduce the water uptake in natural fiber composites is the fibers' surface treatments [31,34-42,145]. The main surface modification methods used for natural fibers (i.e., physical and chemical) were presented in Section 2.2 of this review. Another approach to decrease the water absorption in polymeric composites is to incorporate synthetic fillers which can fill the voids and better distribute the internal stresses in the composites [100,146-148]. For example, a number of researchers have investigated the effects of the incorporation of $\mathrm{TiO}_{2}$ nanofiller and glass powder in the polymer matrix with the objective of delaying the effect of water absorption on composites [100,149].

Several studies have been carried out in the literature concerning the moisture absorption behaviour of hybrid composites, both natural-natural and natural-synthetic fibers reinforced composites [1214,54,71,91,95,143,144,150-159]. Tab. 6 summarises some recent studies on the effect of hybridisation on the water absorption characteristics of hybrid composites. In general, the natural-synthetic hybridisation technique coupled with choosing an optimum fiber content, stacking sequence and fiber orientation, can drastically reduce the moisture content at saturation and decrease the diffusivity coefficient. Therefore, the moisture degradation and composite material property impact is reduced. The water uptake behaviour of natural-natural hybrid composites vary significantly as a function of reinforcement fiber, as different natural fibers present different contents of hydrophilic groups, porosity, crystallinity among other parameters, their water uptake behaviour changes. As such, the natural-natural hybridisation methods provide a viable technique so that a balance may be found in terms of cost/ performance regarding its uses in moisture-rich environments. 
Table 6: Effect of hybridisation on the water absorption behaviour of hybrid composites

\begin{tabular}{|c|c|c|c|}
\hline Composite & Details of the process & $\begin{array}{l}\text { Effect of hybridisation on the } \\
\text { water absorption }\end{array}$ & References \\
\hline $\begin{array}{l}\text { Hemp/jute Hemp/ } \\
\text { flax Hemp/jute/flax } \\
\text { (Epoxy matrix) }\end{array}$ & $\begin{array}{l}\text { Bi-directional woven mats. Hand } \\
\text { lay-up compression technique. }\end{array}$ & $\begin{array}{l}\text { Hemp/jute/epoxy, hemp/jute/flax/ } \\
\text { epoxy and hemp/flax/epoxy } \\
\text { absorbed } 4.5 \%, 3 \% \text { and } 2.8 \% \\
\text { water, respectively. }\end{array}$ & [12] \\
\hline $\begin{array}{l}\text { Kenaf/Jute Kenaf/ } \\
\text { Hemp Kenaf Jute } \\
\text { Hemp (Epoxy) }\end{array}$ & $\begin{array}{l}\text { Vacuum infusion technique. } \\
\text { Interwoven hybrid fabrics. }\end{array}$ & $\begin{array}{l}\text { Both kenaf/jute and kenaf/hemp } \\
\text { hybrids absorbed less water than } \\
\text { the single fiber composites. A } \\
\text { reduction of moisture uptake of up } \\
\text { to } 64 \% \text { was reported. }\end{array}$ & [13] \\
\hline $\begin{array}{l}\text { Kenaf/sisal Kenaf } \\
\text { Sisal (Epoxy) }\end{array}$ & $\begin{array}{l}\text { Plain woven kenaf and sisal } \\
\text { fabrics. Hand lay-up compression } \\
\text { moulding fabrication. Stacking } \\
\text { sequence was varied. }\end{array}$ & $\begin{array}{l}\text { Small variation was observed in } \\
\text { moisture uptake as a function of } \\
\text { hybridisation. The sisal/kenaf/ } \\
\text { sisal case presented the highest } \\
\text { water absorption }(\sim 3.5 \%) \text {. }\end{array}$ & {$[14]$} \\
\hline Kenaf/jute (Epoxy) & $\begin{array}{l}\text { Jute and kenaf fiber mats. Hand } \\
\text { lay-up technique. Two stacking } \\
\text { sequences were fabricated. }\end{array}$ & $\begin{array}{l}\text { The water uptake behaviour } \\
\text { varied significantly as a function } \\
\text { of stacking sequence. The kenaf/ } \\
\text { jute/kenaf (KJK) case presented } \\
\text { the lowest water absorption } \\
(\sim 3.8 \%) \text {. }\end{array}$ & [156] \\
\hline $\begin{array}{l}\text { Date Palm Leaf } \\
\text { (DPL)/glass (Epoxy) }\end{array}$ & $\begin{array}{l}\text { Hand lay-up fabrication. Alkaline } \\
\text { treated short fibers. Glass fiber } \\
\text { fraction was maintained while the } \\
\text { DPL percentage was varied. }\end{array}$ & $\begin{array}{l}\text { The rate of water absorption of the } \\
\text { composites increased by adding } \\
\text { more DPL fiber. Maximum water } \\
\text { uptake was found for the } 30 \mathrm{wt} \% \\
\text { of DPL. }\end{array}$ & {$[160]$} \\
\hline Jute/carbon (Epoxy) & $\begin{array}{l}\text { Plain woven jute fibers was used } \\
\text { along with unidirectional carbon } \\
\text { fabric. Vacuum assisted resin } \\
\text { infusion fabrication method was } \\
\text { applied. The stacking sequence } \\
\text { and fiber orientation was varied. }\end{array}$ & $\begin{array}{l}\text { Similar pattern of water } \\
\text { absorption behaviour was } \\
\text { observed for all cases or fiber } \\
\text { orientation. The stacking } \\
\text { sequence proved to be the most } \\
\text { significant variable, with the } \\
\text { synthetic layers on the outside of } \\
\text { the natural core. The } \mathrm{S} 4\left(\mathrm{C}_{2} \mathrm{~J}_{6} \mathrm{C}_{2}\right) \\
\text { case absorbed the least amount of } \\
\text { moisture. }\end{array}$ & {$[91]$} \\
\hline $\begin{array}{l}\text { Full flax fiber Full } \\
\text { glass fiber Flax/glass } \\
\text { fiber (Epoxy) }\end{array}$ & $\begin{array}{l}\text { Vacuum assisted resin infusion } \\
\text { method. }\end{array}$ & $\begin{array}{l}\text { Water absorption for the flax-fiber } \\
\text { composites was found to be } \\
12 \text { times higher than for the glass- } \\
\text { fiber composites. }\end{array}$ & {$[151]$} \\
\hline
\end{tabular}




\begin{tabular}{|c|c|c|c|}
\hline Composite & Details of the process & $\begin{array}{l}\text { Effect of hybridisation on the } \\
\text { water absorption }\end{array}$ & References \\
\hline $\begin{array}{l}\text { Flax/glass (Vinyl } \\
\text { Ester) }\end{array}$ & $\begin{array}{l}\text { Bi-directional flax and glass fiber } \\
\text { fabrics were used. Hand lay-up } \\
\text { and vacuum infusion fabrication. }\end{array}$ & $\begin{array}{l}\text { Significant decrease in water } \\
\text { absorption was observed as a } \\
\text { function of hybridisation. The } \\
\text { outer synthetic layers play a } \\
\text { significant role in diminishing the } \\
\text { moisture saturation content of } \\
\text { hybrid composites. }\end{array}$ & {$[152]$} \\
\hline $\begin{array}{l}\text { Jute/glass/Carbon } \\
\text { (Epoxy) }\end{array}$ & $\begin{array}{l}\text { Plain weave bi-directional jute } \\
\text { fabrics were used along with } \\
\text { chopped glass mats and twill } \\
\text { weave carbon fabrics. The hand } \\
\text { lay-up process was used and the } \\
\text { stacking sequence was varied. }\end{array}$ & $\begin{array}{l}\text { Significantly lower absorption of } \\
\text { moisture was reported for the } \\
\text { inter-ply hybrid composites } \\
\text { compared to the neat jute. }\end{array}$ & {$[143]$} \\
\hline $\begin{array}{l}4 \text { harness satin } \\
\text { woven carbon fibers } \\
\text { and flax fibers } \\
\text { (Epoxy matrix) }\end{array}$ & Compression molding. & $\begin{array}{l}\text { By covering the inner core of flax } \\
\text { fiber/epoxy with an external layer } \\
\text { of carbon fiber/epoxy the water } \\
\text { absorption was kept to } 4.8 \%- \\
8.3 \% \text {. }\end{array}$ & {$[144]$} \\
\hline $\begin{array}{l}\text { Flax fiber laminates } \\
\text { Glass fiber Flax- } \\
\text { glass composites } \\
\text { (Epoxy) }\end{array}$ & $\begin{array}{l}\text { Compression moulding Different } \\
\text { stacking sequences. }\end{array}$ & $\begin{array}{l}\text { The hybridisation of flax and glass } \\
\text { fibers improved the moisture } \\
\text { resistance of the flax fiber } \\
\text { laminates by reducing the water } \\
\text { absorption and the diffusion } \\
\text { coefficient as well as the thickness } \\
\text { swelling at room temperature. }\end{array}$ & [161] \\
\hline $\begin{array}{l}\text { Jute/glass fiber } \\
\text { reinforced } \\
\text { (Polyester) }\end{array}$ & $\begin{array}{l}\text { Pultrusion. Different stacking } \\
\text { sequences: JJ, GJJG, CGJJGC } \\
\text { and SGJJGS. }\end{array}$ & $\begin{array}{l}\text { The pure jute group displayed a } \\
\text { moisture content at saturation of } \\
47.65 \% \text {, while the glass } \\
\text { reinforced hybrid case }(\mathrm{GJJG}) \\
\text { presented a content of } 13.31 \% \text {. }\end{array}$ & {$[154]$} \\
\hline
\end{tabular}

\section{Challenges, Market Trends and Perspectives}

The global awareness of environmental issues is at an all-time high and NFRCs are nearing the point to become competitive with classical synthetic fiber-reinforced composites. This is leading advancements in nearly every industry as they seek the integration of biodegradable and more cost-efficient materials. However, there are still many challenges and a wide scope for improvement to extend their applications. The main challenges identified as potentially detrimental to market growth are supply logistics, moisture sensitivity and weak interfacial bond of NFRCs. In addition, the natural origin of these fibers, which result in variations in their properties produce large variations in properties, long-term stability and durability of NFRCs. Some of these challenges were addressed by recent development in fibers treatment 
and modification, and process or product innovation (hybridization). Moreover, intense research efforts are in progress to address these limitations.

In this context, there are many exciting market trends going forward in many different industries. For example, tri-dimensional hybrid natural fiber reinforcement preforms have been used recently by sports cars manufacturers such as Porsche and even McLaren in Formula 1 [162]. This application involved the use of flax fibers in a specific 3D architecture to increase stiffness and toughness, lower weight and reduce debris in a crash. It has been successful used in F1 car seats, and the front crash absorbing structure (crash box). Similarly, many other car manufacturers such as Tesla and BMW have been investigating the use of this technique in structural components of the vehicle with promising results. These advances were made commercially available by companies such as Bcomp ${ }^{\circledR}$ and $\mathrm{Ycom}^{\circledR}$ $[162,163]$. Nowadays, Audi, Volkswagen, Toyota, Daimler-Benz, Volvo, Ford use NFRCs to produce components such as: seat back, interior door paneling, noise insulation panels, instrumental panel support, engine insulation, and internal engine cover. The continually growing demands for lightweight and fuelefficient vehicles will further push the growth of NFRCs in the automotive market.

In the defence industry, natural fibers are used as an alternative in replacing Kevlar fibers. For instance, they were used in the Multilayered Armour System (MAS) due to their high impact energy absorption, lowweight, and efficiency in capturing splinters from the ceramic plate typically present in MAS [164]. The curauá based natural fibers reinforced composites, for example, are up-and-coming solutions for these applications as they are being intensely studied recently to be applied in military equipment mainly due to their excellent relationship between weight and strength $[165,166]$.

Another booming area involving natural fibers is the application of natural reinforcements in additive manufactured parts. The advantages using additive manufacture to produce NFRCs and hybrids are the design flexibility to fabricate complex geometry parts or functionally graded composites with localspecific performance and functionality. The use of natural fibers can bring many advantages to single or dispensable production such as production of tailored, non-toxic, renewable, and recyclable parts. The advantages of natural fibers compared to synthetic fibers are especially relevant when considering their lower toll on both printer durability and production cost. However, using natural fibers and additive manufacture (AM) still presents significant challenges such as: composite filament preparation, porosity/ void formation and fiber orientation and large amount of moisture. These issues can be solved by modifying the AM process parameters, hardware and feed stock quality. As the demand for more sustainable material options grows in the general global marketplace, natural fibers coupled with novel processing techniques (e.g., additive manufacturing) can lead to the advancement of many industries towards a smart eco-conscious future.

\section{Conclusions}

The main challenges that need to be addressed in order to increase the performance and consequently the use of NFRCs composites in industry are mainly the poor adhesion between natural fibers and matrix, fiber quality inconsistency, thermal stability and moisture absorption of natural fibers. Intense research efforts are continuously made and some of these challenges were addressed by recent advancements in fibers treatment and modification, exploration of new natural fibers and hybridization. The fiber modification techniques provide improved fibre-matrix interfacial adhesion, improved fibre roughness and wettability and depends on the particular fiber/matrix used and the composite application, while the hybridization methods provide flexibility in fibers selection for the materials properties according to the end-use application requirements. Exploration of new natural fibers, especially, natural fibers with higher strength and modulus, such as curaua or nano-scaled cellulosic fibers, offer a promising potential for expanding the application of these composites. In addition, can diversify fiber sources and reduce material cost. Although, hybridization of natural fiber composites with other natural fibers may not provide comparable 
mechanical or thermal properties improvements to those hybridized with synthetic fibers, this approach may have noteworthy value in terms of sustainability. The hybridisation of natural fibers composites with other fibers characterised by low moisture absorption tendency is an effective method to improve the water absorption resistance of natural hybrid composites. Fiber's treatment and addition of fillers are also solutions to reduce moisture absorption of these composites. The application of natural and hybrid fibers composites, particularly in automotive, civil industry and sports is quite promising and will significantly increase in the future due to the significant pressure on reducing costs and increasing demand for material recyclability.

Funding Statement: The authors acknowledge the National Council for Scientific and Technological Development (CNPq), Coordenação de Aperfeiçoamento de Pessoal de Nível Superior-Brasil (CAPES)Finance Code 001, and Fundação de Amparo à Pesquisa do Estado do Rio de Janeiro (FAPERJ), Brazil.

Conflicts of Interest: The authors declare that they have no conflicts of interest to report regarding the present study.

\section{References}

1. Pickering, K. L., Efendy, M. A., Le, T. M. (2016). A review of recent developments in natural fibre composites and their mechanical performance. Composites Part A: Applied Science and Manufacturing, 83, 98-112. DOI 10.1016/j.compositesa.2015.08.038.

2. Swolfs, Y., Gorbatikh, L., Verpoest, I. (2014). Fibre hybridisation in polymer composites: A review. Composites Part A-Applied Science and Manufacturing, 67, 181-200. DOI 10.1016/j.compositesa.2014.08.027.

3. de Queiroz, H. F. M., Banea, M. D., Cavalcanti, D. K. K., Neto, J. S. S. (2021). The effect of multiscale hybridization on the mechanical properties of natural fiber-reinforced composites. Journal of Applied Polymer Science, 51213. DOI 10.1002/app.51213.

4. Sanjay, M., Siengchin, S., Parameswaranpillai, J., Jawaid, M., Pruncu, C. I. et al. (2019). A comprehensive review of techniques for natural fibers as reinforcement in composites: Preparation, processing and characterization. Carbohydrate Polymers, 207, 108-121. DOI 10.1016/j.carbpol.2018.11.083.

5. Silva, R. V., Aquino, E. M. F. (2008). Curaua fiber: A New alternative to polymeric composites. Journal of Reinforced Plastics and Composites, 27(1), 103-112. DOI 10.1177/0731684407079496.

6. Demosthenes, L. C. C., Nascimento, L. F. C., Monteiro, S. N., Costa, U. O., Garcia Filho, F. C. et al. (2020). Thermal and structural characterization of buriti fibers and their relevance in fabric reinforced composites. Journal of Materials Research and Technology, 9(1), 115-123. DOI 10.1016/j.jmrt.2019.10.036.

7. Latif, R., Wakeel, S., Zaman Khan, N., Noor Siddiquee, A., Lal Verma, S. et al. (2019). Surface treatments of plant fibers and their effects on mechanical properties of fiber-reinforced composites: A review. Journal of Reinforced Plastics and Composites, 38(1), 15-30. DOI 10.1177/0731684418802022.

8. Verma, A., Parashar, A., Jain, N., Singh, V., Rangappa, S. M. et al. (2020). Surface modification techniques for the preparation of different novel biofibers for composites. Biofibers and Biopolymers for Biocomposites, 1-34. DOI 10.1007/978-3-030-40301-0.

9. Lotfi, A., Li, H., Dao, D. V., Prusty, G. (2019). Natural fiber-reinforced composites: A review on material, manufacturing, and machinability. Journal of Thermoplastic Composite Materials, 34(2), 238-284. DOI $10.1177 / 0892705719844546$.

10. Li, M., Pu, Y., Thomas, V. M., Yoo, C. G., Ozcan, S. et al. (2020). Recent advancements of plant-based natural fiber-reinforced composites and their applications. Composites Part B: Engineering, 200, 108254. DOI 10.1016/ j.compositesb.2020.108254.

11. de Queiroz, H. F. M., Banea, M. D., Cavalcanti, D. K. K. (2021). Adhesively bonded joints of jute, glass and hybrid jute/glass fibre-reinforced polymer composites for automotive industry. Applied Adhesion Science, 9(1), 2. DOI 10.1186/s40563-020-00131-6. 
12. Chaudhary, V., Bajpai, P. K., Maheshwari, S. (2020). Effect of moisture absorption on the mechanical performance of natural fiber reinforced woven hybrid bio-composites. Journal of Natural Fibers, 17(1), 84100. DOI 10.1080/15440478.2018.1469451.

13. Maslinda, A. B., Abdul Majid, M. S., Ridzuan, M. J. M., Afendi, M., Gibson, A. G. (2017). Effect of water absorption on the mechanical properties of hybrid interwoven cellulosic-cellulosic fibre reinforced epoxy composites. Composite Structures, 167, 227-237. DOI 10.1016/j.compstruct.2017.02.023.

14. Yorseng, K., Mavinkere Rangappa, S., Parameswaranpillai, J., Siengchin, S. (2020). Influence of accelerated weathering on the mechanical, fracture morphology, thermal stability, contact angle, and water absorption properties of natural fiber fabric-based epoxy hybrid composites. Polymers, 12(10), 2254. DOI 10.3390/ polym 12102254 .

15. Banea, M. D., Neto, J. S. S., Cavalcanti, D. K. K. (2021). Recent trends in surface modification of natural fibres for their use in green composites. Green Composites, 329-350. DOI 10.1007/978-981-15-9643-8.

16. El Messiry, M. (2021). Green composite as an adequate material for automotive applications. Green Composites, 151-208. DOI 10.1007/978-981-15-9643-8.

17. Sanjay, M. R., Madhu, P., Jawaid, M., Senthamaraikannan, P., Senthil, S. et al. (2018). Characterization and properties of natural fiber polymer composites: A comprehensive review. Journal of Cleaner Production, 172, 566-581. DOI 10.1016/j.jclepro.2017.10.101.

18. Gurunathan, T., Mohanty, S., Nayak, S. K. (2015). A review of the recent developments in biocomposites based on natural fibres and their application perspectives. Composites Part A: Applied Science and Manufacturing, 77, 1-25. DOI 10.1016/j.compositesa.2015.06.007.

19. Rong, M. Z., Zhang, M. Q., Liu, Y., Yang, G. C., Zeng, H. M. (2001). The effect of fiber treatment on the mechanical properties of unidirectional sisal-reinforced epoxy composites. Composites Science and Technology, 61(10), 1437-1447. DOI 10.1016/S0266-3538(01)00046-X.

20. Jawaid, M., Khalil, H. A. (2011). Cellulosic/synthetic fibre reinforced polymer hybrid composites: A review. Carbohydrate Polymers, 86(1), 1-18. DOI 10.1016/j.carbpol.2011.04.043.

21. Alves Fidelis, M. E., Pereira, T. V. C., Gomes, O. F. M., de Andrade Silva, F., Toledo Filho, D. R. (2013). The effect of fiber morphology on the tensile strength of natural fibers. Journal of Materials Research and Technology, 2(2), 149-157. DOI 10.1016/j.jmrt.2013.02.003.

22. El Messiry, M. (2017). Natural fiber textile composite engineering. USA: CRC Press.

23. Cavalcanti, D. K. K., Banea, M. D., Neto, J. S. S., Lima, R. A. A., da Silva, L. F. M. et al. (2019). Mechanical characterization of intralaminar natural fibre-reinforced hybrid composites. Composites Part B: Engineering, 175, 107149. DOI 10.1016/j.compositesb.2019.107149.

24. Neto, J. S. S., Lima, R. A. A., Cavalcanti, D. K. K., Souza, J. S. S., Aguiar, R. A. A. et al. (2019). Effect of chemical treatment on the thermal properties of hybrid natural fiber-reinforced composites. Journal of Applied Polymer Science, 136(10), 47154. DOI 10.1002/app.47154.

25. Lima, R. A. A., Cavalcanti, D. K. K., Neto, J. S. S., da Costa, H. M., Banea, M. D. (2020). Effect of surface treatments on interfacial properties of natural intralaminar hybrid composites. Polymer Composites, 41(1), 314-325. DOI 10.1002/pc.25371.

26. Panaitescu, D. M., Nicolae, C. A., Gabor, A. R., Trusca, R. (2020). Thermal and mechanical properties of poly(3hydroxybutyrate) reinforced with cellulose fibers from wood waste. Industrial Crops and Products, 145, 112071. DOI 10.1016/j.indcrop.2019.112071.

27. Soatthiyanon, N., Aumnate, C., Srikulkit, K. (2020). Rheological, tensile, and thermal properties of poly(butylene succinate) composites filled with two types of cellulose (kenaf cellulose fiber and commercial cellulose). Polymer Composites, 41(7), 2777-2791. DOI 10.1002/pc.25575.

28. Rout, J., Misra, M., Tripathy, S. S., Nayak, S. K., Mohanty, A. K. (2001). The influence of fibre treatment on the performance of coir-polyester composites. Composites Science and Technology, 61(9), 1303-1310. DOI 10.1016/ S0266-3538(01)00021-5. 
29. Asim, M., Paridah, M., Saba, N., Jawaid, M., Alothman, O. Y. et al. (2018). Thermal, physical properties and flammability of silane treated kenaf/pineapple leaf fibres phenolic hybrid composites. Composite Structures, 202, 1330-1338. DOI 10.1016/j.compstruct.2018.06.068.

30. Gohil, P. P., Chaudhary, V., Shaikh, A. A. (2015). Natural fiber-reinforced composites: Potential, applications, and properties. Agricultural biomass based potential materials, Switzerland: Springer Nature.

31. Lalit, R., Mayank, P., Ankur, K. (2018). Natural fibers and biopolymers characterization: A future potential composite material. Strojnicky Časopis-Journal of Mechanical Engineering, 68(1), 33-50. DOI 10.2478/ scjme-2018-0004.

32. Sathishkumar, T. P., Navaneethakrishnan, P., Shankar, S., Rajasekar, R., Rajini, N. (2013). Characterization of natural fiber and composites-A review. Journal of Reinforced Plastics and Composites, 32(19), 1457-1476. DOI 10.1177/0731684413495322.

33. Ali, A., Shaker, K., Nawab, Y., Jabbar, M., Hussain, T. et al. (2018). Hydrophobic treatment of natural fibers and their composites-A review. Journal of Industrial Textiles, 47(8), 2153-2183. DOI 10.1177/1528083716654468.

34. Al-Maharma, A. Y., Al-Huniti, N. (2019). Critical review of the parameters affecting the effectiveness of moisture absorption treatments used for natural composites. Journal of Composites Science, 3(1), 27. DOI 10.3390/ jcs3010027.

35. Azwa, Z., Yousif, B., Manalo, A., Karunasena, W. (2013). A review on the degradability of polymeric composites based on natural fibres. Materials \& Design, 47, 424-442. DOI 10.1016/j.matdes.2012.11.025.

36. Gholampour, A., Ozbakkaloglu, T. (2020). A review of natural fiber composites: Properties, modification and processing techniques, characterization, applications. Journal of Materials Science, 1-64. DOI 10.1007/ s10853-019-03990-y.

37. John, M. J., Anandjiwala, R. D. (2008). Recent developments in chemical modification and characterization of natural fiber-reinforced composites. Polymer Composites, 29(2), 187-207. DOI 10.1002/(ISSN)1548-0569.

38. Kalia, S., Kaith, B., Kaur, I. (2009). Pretreatments of natural fibers and their application as reinforcing material in polymer composites-A review. Polymer Engineering \& Science, 49(7), 1253-1272. DOI 10.1002/pen.21328.

39. Koohestani, B., Darban, A., Mokhtari, P., Yilmaz, E., Darezereshki, E. (2019). Comparison of different natural fiber treatments: A literature review. International Journal of Environmental Science and Technology, 16(1), 629642. DOI 10.1007/s13762-018-1890-9.

40. Mahzan, S., Fitri, M., Zaleha, M. (2017). UV radiation effect towards mechanical properties of natural fibre reinforced composite material: A review. IOP Conference Series: Materials Science and Engineering, 165(1), 012021. DOI 10.1088/1757-899X/165/1/012021.

41. Sood, M., Dwivedi, G. (2018). Effect of fiber treatment on flexural properties of natural fiber reinforced composites: A review. Egyptian Journal of Petroleum, 27(4), 775-783. DOI 10.1016/j.ejpe.2017.11.005.

42. Zhou, Y., Fan, M., Chen, L. (2016). Interface and bonding mechanisms of plant fibre composites: An overview. Composites Part B: Engineering, 101, 31-45. DOI 10.1016/j.compositesb.2016.06.055.

43. Ferreira, D. P., Cruz, J., Fangueiro, R. (2019). Surface modification of natural fibers in polymer composites. Green Composites for Automotive Applications, 3-41. DOI 10.1016/B978-0-08-102177-4.00001-X.

44. Beg, M. D. H., Pickering, K. L. (2008). Mechanical performance of kraft fibre reinforced polypropylene composites: Influence of fibre length, fibre beating and hygrothermal ageing. Composites Part A: Applied Science and Manufacturing, 39(11), 1748-1755. DOI 10.1016/j.compositesa.2008.08.003.

45. Sullins, T., Pillay, S., Komus, A., Ning, H. (2017). Hemp fiber reinforced polypropylene composites: The effects of material treatments. Composites Part B: Engineering, 114, 15-22. DOI 10.1016/j.compositesb.2017.02.001.

46. Marques, M. D. V., Melo, R. P., Araujo, R. D., Lunz, J. D., Aguiar, V. D. (2015). Improvement of mechanical properties of natural fiber-polypropylene composites using successive alkaline treatments. Journal of Applied Polymer Science, 132, 1-12. DOI 10.1002/app.41710.

47. Brodowsky, H., Mäder, E. (2012). Jute fibre/epoxy composites: Surface properties and interfacial adhesion. Composites Science and Technology, 72(10), 1160-1166. DOI 10.1016/j.compscitech.2012.03.025. 
48. Cai, M., Takagi, H., Nakagaito, A. N., Li, Y., Waterhouse, G. I. (2016). Effect of alkali treatment on interfacial bonding in abaca fiber-reinforced composites. Composites Part A: Applied Science and Manufacturing, 90, 589597. DOI 10.1016/j.compositesa.2016.08.025.

49. Fiore, V., di Bella, G., Valenza, A. (2015). The effect of alkaline treatment on mechanical properties of kenaf fibers and their epoxy composites. Composites Part B: Engineering, 68, 14-21. DOI 10.1016/j. compositesb.2014.08.025.

50. Fiore, V., Scalici, T., Nicoletti, F., Vitale, G., Prestipino, M. et al. (2016). A new eco-friendly chemical treatment of natural fibres: Effect of sodium bicarbonate on properties of sisal fibre and its epoxy composites. Composites Part B: Engineering, 85, 150-160. DOI 10.1016/j.compositesb.2015.09.028.

51. Aydın, M., Tozlu, H., Kemaloglu, S., Aytac, A., Ozkoc, G. (2011). Effects of alkali treatment on the properties of short flax fiber-poly (lactic acid) eco-composites. Journal of Polymers and the Environment, 19(1), 11-17. DOI 10.1007/s10924-010-0233-9.

52. Wang, F., Lu, M., Zhou, S., Lu, Z. (2019). Effect of fiber surface modification on the interfacial adhesion and thermo-mechanical performance of unidirectional epoxy-based composites reinforced with bamboo fibers. 24(15), 2682. DOI 10.3390/molecules24152682.

53. El Boustani, M., Lebrun, G., Brouillette, F., Belfkira, A. (2017). Effect of a solvent-free acetylation treatment on reinforcements permeability and tensile behaviour of flax/epoxy and flax/wood fibre/epoxy composites. The Canadian Journal of Chemical Engineering, 95(6), 1082-1092. DOI 10.1002/cjce.22777.

54. Safri, S. N., Sultan, M. T., Saba, N., Jawaid, M. (2018). Effect of benzoyl treatment on flexural and compressive properties of sugar palm/glass fibres/epoxy hybrid composites. Polymer Testing, 71, 362-369. DOI 10.1016/j. polymertesting.2018.09.017.

55. Orue, A., Eceiza, A., Arbelaiz, A. (2018). Pretreatments of natural fibers for polymer composite materials. Lignocellulosic Composite Materials, 137-175. DOI 10.1007/978-3-319-68696-7.

56. Vinayagamoorthy, R. (2019). Influence of fiber surface modifications on the mechanical behavior of vetiveria zizanioides reinforced polymer composites. Journal of Natural Fibers, 16(2), 163-174. DOI 10.1080/ 15440478.2017.1410513.

57. Goriparthi, B. K., Suman, K. N. S., Mohan Rao, N. (2012). Effect of fiber surface treatments on mechanical and abrasive wear performance of polylactide/jute composites. Composites Part A: Applied Science and Manufacturing, 43(10), 1800-1808. DOI 10.1016/j.compositesa.2012.05.007.

58. Zafeiropoulos, N. E., Williams, D. R., Baillie, C. A., Matthews, F. L. (2002). Engineering and characterisation of the interface in flax fibre/polypropylene composite materials. Part I. Development and investigation of surface treatments. Composites Part A: Applied Science and Manufacturing, 33(8), 1083-1093. DOI 10.1016/S1359835X(02)00082-9.

59. Alavudeen, A., Rajini, N., Karthikeyan, S., Thiruchitrambalam, M., Venkateshwaren, N. (2015). Mechanical properties of banana/kenaf fiber-reinforced hybrid polyester composites: Effect of woven fabric and random orientation. Materials \& Design (1980-2015), 66, 246-257. DOI 10.1016/j.matdes.2014.10.067.

60. Pérez-Fonseca, A., Robledo-Ortíz, J., Ramirez-Arreola, D., Ortega-Gudiño, P., Rodrigue, D. et al. (2014). Effect of hybridization on the physical and mechanical properties of high density polyethylene-(pine/agave) composites. Materials \& Design, 64, 35-43. DOI 10.1016/j.matdes.2014.07.025.

61. Yashas Gowda, T. G., Sanjay, M. R., Subrahmanya Bhat, K., Madhu, P., Senthamaraikannan, P. et al. (2018). Polymer matrix-natural fiber composites: An overview. Cogent Engineering, 5(1), 1446667. DOI 10.1080/ 23311916.2018 .1446667$.

62. Cao, Y., Wu, Y. Q. (2008). Evaluation of statistical strength of bamboo fiber and mechanical properties of fiber reinforced green composites. Journal of Central South University of Technology, 15(1), 564-567. DOI 10.1007/ s11771-008-0422-z.

63. Favaro, S., Ganzerli, T., de Carvalho Neto, A., da Silva, O., Radovanovic, E. (2010). Chemical, morphological and mechanical analysis of sisal fiber-reinforced recycled high-density polyethylene composites. Express Polymer Letters, 4(8), 465-473. DOI 10.3144/expresspolymlett.2010.59. 
64. Mallick, P. K. (2010). Thermoplastics and thermoplastic-matrix composites for lightweight automotive structures. Materials, design and manufacturing for lightweight vehicles. USA: Woodhead Publishing.

65. Kabir, M. M., Wang, H., Lau, K. T., Cardona, F. (2012). Chemical treatments on plant-based natural fibre reinforced polymer composites: An overview. Composites Part B: Engineering, 43(7), 2883-2892. DOI 10.1016/j.compositesb.2012.04.053.

66. Pereira, A. L., Banea, M. D., Neto, J. S., Cavalcanti, D. K. (2020). Mechanical and thermal characterization of natural intralaminar hybrid composites based on sisal. Polymers, 12(4), 866. DOI 10.3390/polym12040866.

67. Cavalcanti, D. K. K., Banea, M. D., Neto, J. S. S., Lima, R. A. A. (2021). Comparative analysis of the mechanical and thermal properties of polyester and epoxy natural fibre-reinforced hybrid composites. Journal of Composite Materials, 55(12), 1683-1692. DOI 10.1177/0021998320976811.

68. Venkateshwaran, N., Elayaperumal, A., Sathiya, G. (2012). Prediction of tensile properties of hybrid-natural fiber composites. Composites Part B: Engineering, 43(2), 793-796. DOI 10.1016/j.compositesb.2011.08.023.

69. Sathishkumar, T., Naveen, J., Navaneethakrishnan, P., Satheeshkumar, S., Rajini, N. (2017). Characterization of sisal/cotton fibre woven mat reinforced polymer hybrid composites. Journal of Industrial Textiles, 47(4), 429452. DOI 10.1177/1528083716648764.

70. Gupta, M., Deep, V. (2019). Effect of water absorption and stacking sequences on the properties of hybrid sisal/ glass fibre reinforced polyester composite. Proceedings of the Institution of Mechanical Engineers, Part L: Journal of Materials: Design and Applications, 233(10), 2045-2056. DOI 10.1177/1464420718811867.

71. Prasanna Venkatesh, R., Ramanathan, K., Srinivasa Raman, V. (2016). Tensile, flexual, impact and water absorption properties of natural fibre reinforced polyester hybrid composites. Fibres \& Textiles in Eastern Europe, 24(3), 90-94. DOI 10.5604/12303666.1196617.

72. Júnior, J. H. S. A., Júnior, H. L. O., Amico, S. C., Amado, F. D. R. (2012). Study of hybrid intralaminate curaua/ glass composites. Materials \& Design, 42, 111-117. DOI 10.1016/j.matdes.2012.05.044.

73. Asaithambi, B., Ganesan, G. S., Ananda Kumar, S. (2017). Banana/sisal fibers reinforced poly(lactic acid) hybrid biocomposites; influence of chemical modification of BSF towards thermal properties. Polymer Composites, 38(6), 1053-1062. DOI 10.1002/pc.23668.

74. Al-Mosawi Ali, I. (2012). Mechanical properties of plants-synthetic hybrid fibers composites. Research Journal of Engineering Sciences, 1(3), 22-25.

75. Boopalan, M., Niranjanaa, M., Umapathy, M. J. (2013). Study on the mechanical properties and thermal properties of jute and banana fiber reinforced epoxy hybrid composites. Composites Part B: Engineering, 51, 54-57. DOI 10.1016/j.compositesb.2013.02.033.

76. Fragassa, C. (2016). Effect of natural fibers and bio-resins on mechanical properties in hybrid and non-hybrid composites. AIP Conference Proceedings, vol. 1736, no. 1, 020118. AIP Publishing LLC. DOI 10.1063/ 1.4949693.

77. Ku, H., Wang, H., Pattarachaiyakoop, N., Trada, M. (2011). A review on the tensile properties of natural fiber reinforced polymer composites. Composites Part B: Engineering, 42(4), 856-873. DOI 10.1016/j. compositesb.2011.01.010.

78. Ornaghi Jr., H. L., da Silva, H. S. P., Zattera, A. J., Amico, S. C. (2011). Hybridization effect on the mechanical and dynamic mechanical properties of curaua composites. Materials Science and Engineering: A, 528(24), 72857289. DOI 10.1016/j.msea.2011.05.078.

79. Ramesh, M., Palanikumar, K., Reddy, K. H. (2013). Mechanical property evaluation of sisal-jute-glass fiber reinforced polyester composites. Composites Part B: Engineering, 48, 1-9. DOI 10.1016/j. compositesb.2012.12.004.

80. Sudhir, A., Madhukiran, J., Rao, S., Madhusudan, S. (2014). Tensile and flexural properties of sisal/jute hybrid natural fiber composites. International Journal of Modern Engineering Research, 4, 29-35. DOI 10.6084/M9. FIGSHARE.1304944.

81. Zhang, Y. L., Li, Y., Ma, H., Yu, T. (2013). Tensile and interfacial properties of unidirectional flax/glass fiber reinforced hybrid composites. Composites Science and Technology, 88, 172-177. DOI 10.1016/j. compscitech.2013.08.037. 
82. Almeida, J. H. S., Amico, S. C., Botelho, E. C., Amado, F. D. R. (2013). Hybridization effect on the mechanical properties of curaua/glass fiber composites. Composites Part B: Engineering, 55, 492-497. DOI 10.1016/j. compositesb.2013.07.014.

83. Asim, M., Jawaid, M., Abdan, K., Ishak, M. R., Alothman, O. Y. (2018). Effect of hybridization on the mechanical properties of pineapple leaf fiber/Kenaf phenolic hybrid composites. Journal of Renewable Materials, 6(1), 38-46. DOI 10.7569/JRM.2017.634148.

84. Safwan, A., Jawaid, M., Sultan, M. T. H., Hassan, A. (2018). Preliminary study on tensile and impact properties of kenaf/Bamboo fiber reinforced epoxy composites. Journal of Renewable Materials, 6(5), 529-535. DOI 10.7569/JRM.2018.634103.

85. Kumar, R., Ul Haq, M. I., Raina, A., Anand, A. (2019). Industrial applications of natural fibre-reinforced polymer composites-challenges and opportunities. International Journal of Sustainable Engineering, 12(3), 212-220. DOI 10.1080/19397038.2018.1538267.

86. Yahaya, R., Sapuan, S. M., Jawaid, M., Leman, Z., Zainudin, E. S. (2015). Effect of layering sequence and chemical treatment on the mechanical properties of woven kenaf-aramid hybrid laminated composites. Materials \& Design, 67, 173-179. DOI 10.1016/j.matdes.2014.11.024.

87. Naveen, J., Jawaid, M., Zainudin, E., Sultan, M. T., Yahaya, R. et al. (2019). Thermal degradation and viscoelastic properties of Kevlar/Cocos nucifera sheath reinforced epoxy hybrid composites. Composite Structures, 219, 194-202. DOI 10.1016/j.compstruct.2019.03.079.

88. Ramesh, M., Palanikumar, K., Reddy, K. H. (2016). Influence of fiber orientation and fiber content on properties of sisal-jute-glass fiber-reinforced polyester composites. Journal of Applied Polymer Science, 133(6). DOI 10.1002/app.42968.

89. Yahaya, R., Sapuan, S. M., Jawaid, M., Leman, Z., Zainudin, E. S. (2016). Effect of fibre orientations on the mechanical properties of kenaf-aramid hybrid composites for spall-liner application. Defence Technology, 12(1), 52-58. DOI 10.1016/j.dt.2015.08.005.

90. Swain, P. T. R., Biswas, S. (2017). Influence of fiber surface treatments on physico-mechanical behaviour of jute/ epoxy composites impregnated with aluminium oxide filler. Journal of Composite Materials, 51(28), 3909-3922. DOI 10.1177/0021998317695420.

91. Sujon, M. A. S., Habib, M. A., Abedin, M. Z. (2020). Experimental investigation of the mechanical and water absorption properties on fiber stacking sequence and orientation of jute/carbon epoxy hybrid composites. Journal of Materials Research and Technology, 9(5), 10970-10981. DOI 10.1016/j.jmrt.2020.07.079.

92. Selver, E., Ucar, N., Gulmez, T. (2018). Effect of stacking sequence on tensile, flexural and thermomechanical properties of hybrid flax/glass and jute/glass thermoset composites. Journal of Industrial Textiles, 48(2), 494520. DOI 10.1177/1528083717736102.

93. Mishra, S., Mohanty, A. K., Drzal, L. T., Misra, M., Parija, S. et al. (2003). Studies on mechanical performance of biofibre/glass reinforced polyester hybrid composites. Composites Science and Technology, 63(10), 1377-1385. DOI 10.1016/S0266-3538(03)00084-8.

94. Ramesh, M., Palanikumar, K., Hemachandra Reddy, K. (2014). Impact behaviour analysis of Sisal/Jute and glass fiber reinforced hybrid composites. Advanced Materials Research, 984-985, 266-272. DOI 10.4028/www. scientific.net/AMR.984-985.266.

95. Aji, I. S., Zainudin, E. S., Khalina, A., Sapuan, S. M., Khairul, M. D. (2011). Studying the effect of fiber size and fiber loading on the mechanical properties of hybridized kenaf/PALF-reinforced HDPE composite. Journal of Reinforced Plastics and Composites, 30(6), 546-553. DOI 10.1177/0731684411399141.

96. Arthanarieswaran, V. P., Kumaravel, A., Kathirselvam, M. (2014). Evaluation of mechanical properties of banana and sisal fiber reinforced epoxy composites: Influence of glass fiber hybridization. Materials \& Design, 64, 194202. DOI 10.1016/j.matdes.2014.07.058.

97. Ramnath, B. V., Rajesh, S., Elanchezhian, C., Shankar, A. S., Pandian, S. P. et al. (2016). Investigation on mechanical behaviour of twisted natural fiber hybrid composite fabricated by vacuum assisted compression molding technique. Fibers and Polymers, 17(1), 80-87. DOI 10.1007/s12221-016-5276-7. 
98. Devireddy, S. B. R., Biswas, S. (2016). Physical and thermal properties of unidirectional banana-jute hybrid fiber-reinforced epoxy composites. Journal of Reinforced Plastics and Composites, 35(15), 1157-1172. DOI $10.1177 / 0731684416642877$.

99. Arun Prakash, V. R., Viswanthan, R. (2019). Fabrication and characterization of echinoidea spike particles and kenaf natural fibre-reinforced azadirachta-indica blended epoxy multi-hybrid bio composite. Composites Part A: Applied Science and Manufacturing, 118, 317-326. DOI 10.1016/j.compositesa.2019.01.008.

100. Prasad, V., Joseph, M. A., Sekar, K. (2018). Investigation of mechanical, thermal and water absorption properties of flax fibre reinforced epoxy composite with nano $\mathrm{TiO}_{2}$ addition. Composites Part A: Applied Science and Manufacturing, 115, 360-370. DOI 10.1016/j.compositesa.2018.09.031.

101. Ramakrishnan, S., Krishnamurthy, K., Rajasekar, R., Rajeshkumar, G. (2019). An experimental study on the effect of nano-clay addition on mechanical and water absorption behaviour of jute fibre reinforced epoxy composites. Journal of Industrial Textiles, 49(5), 597-620. DOI 10.1177/1528083718792915.

102. Sumesh, K. R., Kanthavel, K. (2020). Effect of $\mathrm{TiO}_{2}$ nano-filler in mechanical and free vibration damping behavior of hybrid natural fiber composites. Journal of the Brazilian Society of Mechanical Sciences and Engineering, 42(4), 211. DOI 10.1007/s40430-020-02308-3.

103. Dhakal, H. N., Zhang, Z. Y., Guthrie, R., MacMullen, J., Bennett, N. (2013). Development of flax/carbon fibre hybrid composites for enhanced properties. Carbohydrate Polymers, 96(1), 1-8. DOI 10.1016/j. carbpol.2013.03.074.

104. Saba, N., Jawaid, M. (2018). A review on thermomechanical properties of polymers and fibers reinforced polymer composites. Journal of Industrial and Engineering Chemistry, 67, 1-11. DOI 10.1016/j. jiec.2018.06.018.

105. Saba, N., Jawaid, M., Alothman, O. Y., Paridah, M. (2016). A review on dynamic mechanical properties of natural fibre reinforced polymer composites. Construction and Building Materials, 106, 149-159. DOI 10.1016/j.conbuildmat.2015.12.075.

106. Kumar, T. S. M., Senthilkumar, K., Chandrasekar, M., Subramaniam, S., Rangappa, S. M. et al. (2020). Influence of fillers on the thermal and mechanical properties of biocomposites: An overview. Biofibers and Biopolymers for Biocomposites, 111-133. DOI 10.1007/978-3-030-40301-0.

107. Krishnasamy, S., Thiagamani, S. M. K., Kumar, C. M., Nagarajan, R., Shahroze, R. et al. (2019). Recent advances in thermal properties of hybrid cellulosic fiber reinforced polymer composites. International Journal of Biological Macromolecules, 141, 1-13. DOI 10.1016/j.ijbiomac.2019.08.231.

108. Asim, M., Jawaid, M., Paridah, M. T., Saba, N., Nasir, M. et al. (2019). Dynamic and thermo-mechanical properties of hybridized kenaf/PALF reinforced phenolic composites. Polymer Composites, 40(10), 38143822. DOI 10.1002/pc.25240.

109. Lin, S. Y. (2016). An overview of advanced hyphenated techniques for simultaneous analysis and characterization of polymeric materials. Critical Reviews in Solid State and Materials Sciences, 41(6), 482530. DOI 10.1080/10408436.2016.1186598.

110. Asim, M., Paridah, M. T., Chandrasekar, M., Shahroze, R. M., Jawaid, M. et al. (2020). Thermal stability of natural fibers and their polymer composites. Iranian Polymer Journal, 29, 625-648. DOI 10.1007/s13726020-00824-6.

111. Guo, Y., Zhu, S., Chen, Y., Li, D. (2019). Thermal properties of wood-plastic composites with different compositions. Materials, 12(6), 881. DOI 10.3390/ma12060881.

112. Członka, S., Strąkowska, A., Kairytè, A. (2020). Effect of walnut shells and silanized walnut shells on the mechanical and thermal properties of rigid polyurethane foams. Polymer Testing, 87, 106534. DOI 10.1016/j. polymertesting.2020.106534.

113. Jawaid, M., Khalil, H. A., Bakar, A. A., Hassan, A., Dungani, R. (2013). Effect of jute fibre loading on the mechanical and thermal properties of oil palm-epoxy composites. Journal of Composite Materials, 47(13), 1633-1641. DOI 10.1177/0021998312450305. 
114. Dalla Libera Junior, V., Leão, R. M., Franco Steier, V., da Luz, S. M. (2020). Influence of cure agent, treatment and fibre content on the thermal behaviour of a curaua/epoxy prepreg. Plastics, Rubber and Composites, 49(5), 214-221. DOI 10.1080/14658011.2020.1729658.

115. Braga, R. A., Magalhaes, P. A. A. (2015). Analysis of the mechanical and thermal properties of jute and glass fiber as reinforcement epoxy hybrid composites. Materials Science and Engineering: C, 56, 269-273. DOI 10.1016/j. msec.2015.06.031.

116. Saw, S. K., Datta, C. (2009). Thermo mechanical properties of jute/bagasse hybrid fibre reinforced epoxy thermoset composites. BioResources, 4(4), 1455-1475.

117. Aji, I., Zainudin, E., Khalina, A., Sapuan, S., Khairul, M. (2011). Thermal property determination of hybridized kenaf/PALF reinforced HDPE composite by thermogravimetric analysis. Journal of Thermal Analysis and Calorimetry, 109(2), 893-900. DOI 10.1007/s10973-011-1807-z.

118. Chandrasekar, M., Ishak, M., Sapuan, S., Leman, Z., Jawaid, M. (2017). A review on the characterisation of natural fibres and their composites after alkali treatment and water absorption. Plastics, Rubber and Composites, 46(3), 119-136. DOI 10.1080/14658011.2017.1298550.

119. Gupta, M. (2018). Thermal and dynamic mechanical analysis of hybrid jute/sisal fibre reinforced epoxy composite. Proceedings of the Institution of Mechanical Engineers, Part L: Journal of Materials: Design and Applications, 232(9), 743-748. DOI 10.1177/1464420716646398.

120. Aisyah, H., Paridah, M., Sapuan, S., Khalina, A., Berkalp, O. et al. (2019). Thermal properties of woven Kenaf/ Carbon fibre-reinforced epoxy hybrid composite panels. International Journal of Polymer Science, 8. DOI $10.1155 / 2019 / 5258621$.

121. Safri, S. N. A., Sultan, M. T. H., Shah, A. U. M. (2020). Characterization of benzoyl treated sugar palm/glass fibre hybrid composites. Journal of Materials Research and Technology, 9(5), 11563-11573. DOI 10.1016/j. jmrt.2020.08.057.

122. Lu, N., Oza, S. (2013). A comparative study of the mechanical properties of hemp fiber with virgin and recycled high density polyethylene matrix. Composites Part B: Engineering, 45(1), 1651-1656. DOI 10.1016/j. compositesb.2012.09.076.

123. Jawaid, M., Khalil, H. A., Hassan, A., Dungani, R., Hadiyane, A. (2013). Effect of jute fibre loading on tensile and dynamic mechanical properties of oil palm epoxy composites. Composites Part B: Engineering, 45(1), 619624. DOI 10.1016/j.compositesb.2012.04.068.

124. Ashok, R., Srinivasa, C., Basavaraju, B. (2019). Dynamic mechanical properties of natural fiber composites-A review. Advanced Composites and Hybrid Materials, 2, 586-607. DOI 10.1007/s42114-019-00121-8.

125. Fiore, V., Calabrese, L. (2019). Effect of stacking sequence and sodium bicarbonate treatment on quasi-static and dynamic mechanical properties of flax/jute epoxy-based composites. Materials, 12(9), 1363. DOI 10.3390/ ma12091363.

126. Chee, S. S., Jawaid, M., Sultan, M., Alothman, O. Y., Abdullah, L. C. (2019). Thermomechanical and dynamic mechanical properties of bamboo/woven kenaf mat reinforced epoxy hybrid composites. Composites Part B: Engineering, 163, 165-174. DOI 10.1016/j.compositesb.2018.11.039.

127. Mazlan, N., Chai Hua, T., Sultan, M. T. H., Abdan, K. (2020). Thermogravimetric and dynamic mechanical analysis of woven glass/kenaf/epoxy hybrid nanocomposite filled with clay. Advances in Materials and Processing Technologies, 7, 1-14. DOI 10.1080/2374068X.2020.1755114.

128. Asim, M., Jawaid, M., Nasir, M., Saba, N. (2018). Effect of fiber loadings and treatment on dynamic mechanical, thermal and flammability properties of pineapple leaf fiber and kenaf phenolic composites. Journal of Renewable Materials, 6(4), 383-393. DOI 10.7569/JRM.2017.634162.

129. Khan, T., Sultan, M. T. H., Jawaid, M., Safri, S. N. A., Shah, A. U. M. et al. (2021). The effects of stacking sequence on dynamic mechanical properties and thermal degradation of kenaf/Jute hybrid composites. Journal of Renewable Materials, 9(1), 73-84. DOI 10.32604/jrm.2021.011385.

130. Nurazzi, N. M., Khalina, A., Sapuan, S., Ilyas, R., Rafiqah, S. A. et al. (2020). Thermal properties of treated sugar palm yarn/glass fiber reinforced unsaturated polyester hybrid composites. Journal of Materials Research and Technology, 9(2), 1606-1618. DOI 10.1016/j.jmrt.2019.11.086. 
JRM, 2022, vol.10, no.3

131. Portella, E. H., Romanzini, D., Angrizani, C. C., Amico, S. C., Zattera, A. J. (2016). Influence of stacking sequence on the mechanical and dynamic mechanical properties of cotton/glass fiber reinforced polyester composites. Materials Research, 19(3), 542-547. DOI 10.1590/1980-5373-MR-2016-0058.

132. Saw, S. K., Sarkhel, G., Choudhury, A. (2012). Preparation and characterization of chemically modified jute-Coir hybrid fiber reinforced epoxy novolac composites. Journal of Applied Polymer Science, 125(4), 3038-3049. DOI 10.1002/app.36610.

133. Safri, S. N. A., Sultan, M. T. H., Jawaid, M., Abdul Majid, M. S. (2019). Analysis of dynamic mechanical, lowvelocity impact and compression after impact behaviour of benzoyl treated sugar palm/glass/epoxy composites. Composite Structures, 226, 111308. DOI 10.1016/j.compstruct.2019.111308.

134. Zin, M. H., Abdan, K., Norizan, M. N. (2019). 1-The effect of different fiber loading on flexural and thermal properties of banana/pineapple leaf (PALF)/glass hybrid composite. Structural Health Monitoring of Biocomposites. Fibre-Reinforced Composites and Hybrid Composites, 1-17. DOI 10.1016/B978-0-08102291-7.00001-0.

135. Sathiyamoorthy, M., Senthilkumar, S. (2020). Mechanical, thermal, and water absorption behaviour of jute/ carbon reinforced hybrid composites. Sādhanā, 45(1), 278. DOI 10.1007/s12046-020-01514-y.

136. Chilali, A., Assarar, M., Zouari, W., Kebir, H., Ayad, R. (2017). Effect of geometric dimensions and fibre orientation on 3D moisture diffusion in flax fibre reinforced thermoplastic and thermosetting composites. Composites Part A: Applied Science and Manufacturing, 95, 75-86. DOI 10.1016/j.compositesa.2016.12.020.

137. Mrad, H., Alix, S., Migneault, S., Koubaa, A., Perré, P. (2018). Numerical and experimental assessment of water absorption of wood-polymer composites. Measurement, 115, 197-203. DOI 10.1016/j. measurement.2017.10.011.

138. Sari, N. H., Pruncu, C. I., Sapuan, S. M., Ilyas, R. A., Catur, A. D. et al. (2020). The effect of water immersion and fibre content on properties of corn husk fibres reinforced thermoset polyester composite. Polymer Testing, 91, 106751. DOI 10.1016/j.polymertesting.2020.106751.

139. Dhakal, H. N., Zhang, Z. Y., Richardson, M. O. W. (2007). Effect of water absorption on the mechanical properties of hemp fibre reinforced unsaturated polyester composites. Composites Science and Technology, 67(7), 1674-1683. DOI 10.1016/j.compscitech.2006.06.019.

140. Shen, C. H., Springer, G. S. (1976). Moisture absorption and desorption of composite materials. Journal of Composite Materials, 10(1), 2-20. DOI 10.1177/002199837601000101.

141. Joseph, P. V., Rabello, M. S., Mattoso, L. H. C., Joseph, K., Thomas, S. (2002). Environmental effects on the degradation behaviour of sisal fibre reinforced polypropylene composites. Composites Science and Technology, 62(10), 1357-1372. DOI 10.1016/S0266-3538(02)00080-5.

142. Mehdikhani, M., Gorbatikh, L., Verpoest, I., Lomov, S. V. (2018). Voids in fiber-reinforced polymer composites: A review on their formation, characteristics, and effects on mechanical performance. Journal of Composite Materials, 53(12), 1579-1669. DOI 10.1177/0021998318772152.

143. Abd El-baky, M. A., Attia, M. A. (2018). Water absorption effect on the in-plane shear properties of jute-glasscarbon-reinforced composites using iosipescu test. Journal of Composite Materials, 53(21), 3033-3045. DOI $10.1177 / 0021998318809525$.

144. Al-Hajaj, Z., Zdero, R., Bougherara, H. (2018). Mechanical, morphological, and water absorption properties of a new hybrid composite material made from 4 harness satin woven carbon fibres and flax fibres in an epoxy matrix. Composites Part A: Applied Science and Manufacturing, 115, 46-56. DOI 10.1016/j. compositesa.2018.09.015.

145. Liu, M., Thygesen, A., Summerscales, J., Meyer, A. S. (2017). Targeted pre-treatment of hemp bast fibres for optimal performance in biocomposite materials: A review. Industrial Crops and Products, 108, 660-683. DOI 10.1016/j.indcrop.2017.07.027.

146. Pinto, D., Bernardo, L., Amaro, A., Lopes, S. (2015). Mechanical properties of epoxy nanocomposites using titanium dioxide as reinforcement-A review. Construction and Building Materials, 95, 506-524. DOI 10.1016/j.conbuildmat.2015.07.124. 
147. Alamri, H., Low, I. M. (2012). Effect of water absorption on the mechanical properties of nano-filler reinforced epoxy nanocomposites. Materials \& Design, 42, 214-222. DOI 10.1016/j.matdes.2012.05.060.

148. Miao, Y. G., Liu, H. Y., Suo, T., Mai, Y. W., Xie, F. Q. et al. (2016). Effects of strain rate on mechanical properties of nanosilica/epoxy. Composites Part B: Engineering, 96, 119-124. DOI 10.1016/j.compositesb.2016.04.008.

149. Nayak, R. K., Mahato, K. K., Ray, B. C. (2016). Water absorption behavior, mechanical and thermal properties of nano $\mathrm{TiO}_{2}$ enhanced glass fiber reinforced polymer composites. Composites Part A: Applied Science and Manufacturing, 90, 736-747. DOI 10.1016/j.compositesa.2016.09.003.

150. Chang, B. P., Mohanty, A. K., Misra, M. (2020). Studies on durability of sustainable biobased composites: A review. RSC Advances, 10(31), 17955-17999. DOI 10.1039/C9RA09554C.

151. Calabrese, L., Fiore, V., Scalici, T., Valenza, A. (2019). Experimental assessment of the improved properties during aging of flax/glass hybrid composite laminates for marine applications. Journal of Applied Polymer Science, 136(14), 47203. DOI 10.1002/app.47203.

152. Paturel, A., Dhakal, H. N. (2020). Influence of water absorption on the low velocity falling weight impact damage behaviour of flax/glass reinforced vinyl ester hybrid composites. Molecules, 25(2), 278. DOI 10.3390/ molecules 25020278.

153. Cheng, M., Zhong, Y., Kureemun, U., Cao, D., Hu, H. et al. (2020). Environmental durability of carbon/flax fiber hybrid composites. Composite Structures, 234, 111719. DOI 10.1016/j.compstruct.2019.111719.

154. Akil, H. M., Santulli, C., Sarasini, F., Tirillò, J., Valente, T. (2014). Environmental effects on the mechanical behaviour of pultruded jute/glass fibre-reinforced polyester hybrid composites. Composites Science and Technology, 94, 62-70. DOI 10.1016/j.compscitech.2014.01.017.

155. Sekar, S., Suresh Kumar, S., Vigneshwaran, S., Velmurugan, G. (2020). Evaluation of mechanical and water absorption behavior of natural fiber-reinforced hybrid biocomposites. Journal of Natural Fibers, 1-11. DOI 10.1080/15440478.2020.1788487.

156. Khan, T., Jawaid, M., Sultan, H. (2019). Physical performance of kenaf/jute mat reinforced epoxy hybrid composites. International Journal of Engineering \& Technology Sciences, 8.

157. Venkateshwaran, N., ElayaPerumal, A., Alavudeen, A., Thiruchitrambalam, M. (2011). Mechanical and water absorption behaviour of banana/sisal reinforced hybrid composites. Materials \& Design, 32(7), 4017-4021. DOI 10.1016/j.matdes.2011.03.002.

158. Venkateshwaran, N., ElayaPerumal, A. (2012). Mechanical and water absorption properties of woven jute/banana hybrid composites. Fibers and Polymers, 13(7), 907-914. DOI 10.1007/s12221-012-0907-0.

159. Athijayamani, A., Thiruchitrambalam, M., Natarajan, U., Pazhanivel, B. (2009). Effect of moisture absorption on the mechanical properties of randomly oriented natural fibers/polyester hybrid composite. Materials Science and Engineering: A, 517(1), 344-353. DOI 10.1016/j.msea.2009.04.027.

160. Swain, P. T. R., Das, S. N., Patnaik, P. K., Purohit, A. (2020). The influence of moisture absorption on the mechanical and thermal properties of chemically treated DPL reinforced hybrid composite. Materials Science Forum, 978, 316-322. DOI 10.4028/www.scientific.net/MSF.978.316.

161. Saidane, E. H., Scida, D., Assarar, M., Sabhi, H., Ayad, R. (2016). Hybridisation effect on diffusion kinetic and tensile mechanical behaviour of epoxy based flax-glass composites. Composites Part A: Applied Science and Manufacturing, 87, 153-160. DOI 10.1016/j.compositesa.2016.04.023.

162. Akampumuza, O., Wambua, P. M., Ahmed, A., Li, W., Qin, X. H. (2017). Review of the applications of biocomposites in the automotive industry. Polymer Composites, 38(11), 2553-2569. DOI 10.1002/pc.23847.

163. Mathijsen, D. (2018). The renaissance of flax fibers. Reinforced Plastics, 62(3), 138-147. DOI 10.1016/j. repl.2017.11.020.

164. Odesanya, K. O., Ahmad, R., Jawaid, M., Bingol, S., Adebayo, G. O. et al. (2021). Natural fibre-reinforced composite for ballistic applications: A review. Journal of Polymers and the Environment, 1-18. DOI 10.1007/ s10924-021-02169-4. 
JRM, 2022, vol.10, no.3

165. Braga, F. O., Bolzan, L. T., Lima, Jr., É. P., Monteiro, S. N. (2017). Performance of natural curaua fiber-reinforced polyester composites under $7.62 \mathrm{~mm}$ bullet impact as a stand-alone ballistic armor. Journal of Materials Research and Technology, 6(4), 323-328. DOI 10.1016/j.jmrt.2017.08.003.

166. Braga, F. D. O., Bolzan, L. T., Luz, F. S. D., Lopes, P. H. L. M., Lima, Jr., É. P. et al. (2017). High energy ballistic and fracture comparison between multilayered armor systems using non-woven curaua fabric composites and aramid laminates. Journal of Materials Research and Technology, 6(4), 417-422. DOI 10.1016/j. jmrt.2017.08.001. 